OPEN ACCESS

Edited by:

Adam Mamelak,

Cedars Sinai Medical Center,

United States

Reviewed by:

Thierry C. Brue,

Aix-Marseille Université, France

Maria Chiara Zatelli,

University of Ferrara, Italy

*Correspondence:

Toru Tateno

tateno@ualberta.ca

Takako Araki

taraki@umn.edu

${ }^{\text {t}}$ These authors have contributed

equally to this work

${ }^{\text {t}}$ These authors share last authorship

Specialty section: This article was submitted to Pituitary Endocrinology, a section of the journal

Frontiers in Endocrinology

Received: 31 October 2020 Accepted: 12 January 2021

Published: 26 March 2021

Citation:

Nakano-Tateno T, Lau KJ, Wang J, McMahon C, Kawakami Y, Tateno T

and Araki T (2021) Multimodal

Non-Surgical Treatments of

Aggressive Pituitary Tumors.

Front. Endocrinol. 12:624686. doi: 10.3389/fendo.2021.624686

\section{Multimodal Non-Surgical Treatments of Aggressive Pituitary Tumors}

\author{
Tae Nakano-Tateno ${ }^{1 \dagger}$, Kheng Joe Lau ${ }^{2 \dagger}$, Justin Wang ${ }^{3 \dagger}$, Cailin McMahon ${ }^{3}$, \\ Yasuhiko Kawakami ${ }^{3,4}$, Toru Tateno ${ }^{1 * \neq}$ and Takako Araki ${ }^{2 *}$ \\ ${ }^{1}$ Division of Endocrinology and Metabolism, Department of Medicine, University of Alberta, Edmonton, AB, Canada, \\ 2 Division of Diabetes, Endocrinology and Metabolism, Department of Medicine, University of Minnesota, Minneapolis, MN, \\ United States, ${ }^{3}$ Department of Genetics, Cell Biology, and Development, University of Minnesota, Minneapolis, MN, \\ United States, ${ }^{4}$ Stem Cell Institute, University of Minnesota, Minneapolis, MN, United States
}

Up to $35 \%$ of aggressive pituitary tumors recur and significantly affect mortality and quality of life. Management can be challenging and often requires multimodal treatment. Current treatment options, including surgery, conventional medical therapies such as dopamine agonists, somatostatin receptor agonists and radiotherapy, often fail to inhibit pituitary tumor growth. Recently, anti-tumor effects of chemotherapeutic drugs such as Temozolomide, Capecitabine, and Everolimus, as well as peptide receptor radionuclide therapy on aggressive pituitary tumors have been increasingly investigated and yield mixed, although sometimes promising, outcomes. The purpose of this review is to provide thorough information on non-surgical medical therapies and their efficacies and used protocols for aggressive pituitary adenomas from pre-clinical level to clinical use.

Keywords: non-surgical therapy, Temozolomide, CAPTEM, PRRT (Peptide Receptor Radionuclide Therapy), aggressive pituitary tumors, pituitary carcinomas

\section{INTRODUCTION}

Pituitary tumors are mostly benign and progress slowly. Most of them are non-invasive and cured by surgery or controlled by long-term pharmacologic treatment. However, some pituitary tumors exhibit continued growth despite conventional therapies, including multiple surgeries, radiotherapy, and medical treatment (1). Recent evidence suggests that Temozolomide (TMZ), an alkylating agent, can be used as a valuable first-line chemotherapy for treatment of aggressive pituitary tumors and carcinomas (1). However, some patients may not respond to TMZ. Moreover, many patients experience disease progression or disease recurrence after completion of TMZ treatment, although tumors and carcinomas regressed during the treatment (1-13). In order to ensure long-term positive outcomes in cases of aggressive pituitary tumors, alternative treatment options are needed. Recent case reports showed that TMZ in combination with capecitabine had an improved progression free survival in aggressive pituitary tumors $(14,15)$. Moreover, several new therapies have been reported. These novel therapies include peptide receptor radionuclide therapy (PRRT) (16-24) and treatment with mTOR inhibitors $(11,25-27)$, epidermal growth factor receptor (EGFR) inhibitors (28), immune checkpoint inhibitors (29-31), cyclin dependent kinase (Cdk) inhibitors (32), or vitamin A derivatives $(33,34)$. In this review, we describe the mechanisms, efficacies, and protocols of each treatment and summarize the studies and cases published in the literature. 


\section{TEMOZOLOMIDE (TMZ)}

TMZ is an orally-administered alkylating agent that was originally used for treatment of glioblastomas combined with radiation therapy (35). TMZ was first used in 2006 to manage high-risk pituitary tumors (36-38). TMZ induces methylation of guanine residue at the $\mathrm{O} 6$ position in the DNA. O6methylguanine incorrectly pairs with thymine and triggers the mismatch repair system, leading to the formation of doublestrand breaks in the genome, which causes cell cycle arrest and induction of apoptosis (39).

TMZ was recommended as first-line chemotherapy for aggressive pituitary tumors and carcinomas by the European Society of Endocrinology in 2018 (1) and usually elicits an immediate response. The standard dose of TMZ is $150-200$ $\mathrm{mg} / \mathrm{m}^{2}$ for 5 consecutive days every 28 days ( $=1$ cycle) for at least six cycles (1) (Figure 1A). TMZ is a generally well-tolerated therapy. The major side effects are fatigue and nausea. Twelve studies with greater than five patients have been published since the first case of TMZ use in the management of aggressive pituitary tumors in $2006(2-13)$ (Table 1). The total cumulative number of patients is 366 , including 113 with pituitary carcinomas. Although follow-up duration and definition of a response differed among studies, the overall response in the reduction of tumor size ranged from 33\%$87 \%$. In the largest study by the European Society of Endocrinology, 166 patients were treated with TMZ as firstline chemotherapy. $37 \%$ of the patients showed radiological response and $33 \%$ showed stable disease (11). Similarly, the second largest study with 47 patients, including 13 with pituitary carcinomas, reported that $37 \%$ of patients exhibited tumor size reduction following TMZ treatment (13). In a meta- analysis of 106 patients from 11 studies of aggressive pituitary tumors, $47 \%$ of the patients showed reduction in tumor size (1).

TMZ treatment outcome differs between hormone secreting and non-hormone secreting pituitary tumors. A review of 8 case series encompassing 100 pituitary tumor cases treated with TMZ showed that corticotroph adenomas and prolactinomas have about a $56 \%$ and $44 \%$ tumor reduction rate, respectively. In contrast, nonfunctioning pituitary adenomas have only a $22 \%$ of tumor response rate (40). Two other studies also showed that patients with functioning tumors exhibited better tumor size reduction after treatment with TMZ compared to those with NFPAs $(2,11)$.

As mentioned above, immediate responses to TMZ are mostly favorable; however, tumor progression and relapse frequently occur during long-term follow-up (33\%-63\%) (Table 1). In two large-scale studies with long-term follow-up, tumor relapse occurred in $46 \%$ (16 month follow up with 5 months after cessation) and 38\% (21 months follow-up with 12 months after cessation) of patients, respectively $(2,11)$. In another study that focused on long-term effects of TMZ, up to $63 \%$ of the patients demonstrated disease progression after a median of 16 months following initiation of TMZ (13). Longer TMZ treatment duration (more than 12 cycles) was found to be associated with better survival free of tumor-progression (1, 2, $11,41)$. A retrospective analysis showed higher survival rate in the long-term treatment group (longer than 12 months) compared to the short-term (1-12 months) treatment group [5-year overall survival $92 \%$ vs $54 \%$ (41)], suggesting that longer treatment cycles can increase the likelihood of sustained remission. However, reports from many cases showed that a second course of TMZ failed to induce tumor regression if tumor progression or systemic metastases occurred after an initial treatment $(2,8,10,42,43)$. Therefore, re-challenging with
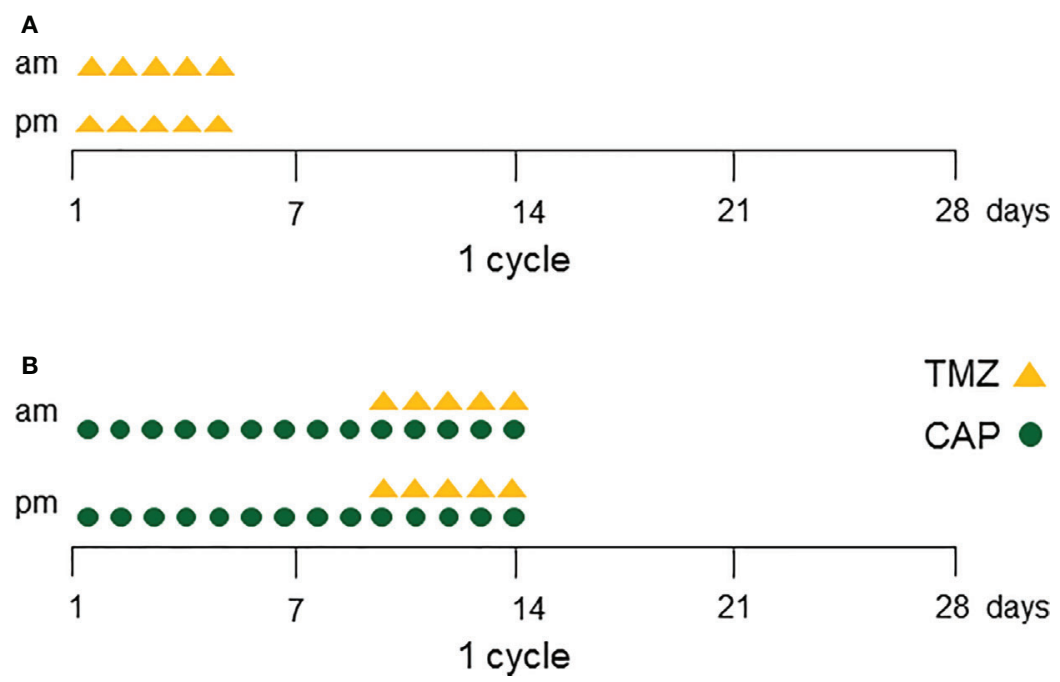

FIGURE 1 | (A) One cycle of Temozolomide (TMZ) protocol. TMZ is given twice daily (150-200 mg/m²/day) for 5 consecutive days every 28 days (=1 cycle). After three cycles of TMZ, MRI is taken for treatment evaluation. Continue TMZ at least six cycles in total for responder patients. (B) One cycle of Capecitabine (pro-drug of 5-Fluorouracil) + Temozolomide (CAPTEM) protocol. Oral capecitabine (CAP) is given (1,500 mg/m²/day) on days 1 through 14 divided into two doses, and TMZ is given twice daily (150 to $200 \mathrm{mg} / \mathrm{m}^{2} /$ day) on days 10 through 14 . This 2 -week regimen is followed by 2 weeks off treatment. Continue CAPTEM at least 12 cycles in total for responder patients. 
TABLE 1 | Temozolomide (TMZ) treatment response in pituitary tumors and carcinomas from published case series of 5 or more patients.

\begin{tabular}{|c|c|c|c|c|c|c|}
\hline response in tumor growth with medication & $\begin{array}{c}\text { TMZ (cycles) } \\
\text { follow-up } \\
\text { (months) }\end{array}$ & $\begin{array}{l}\text { follow-up } \\
\text { (months) }\end{array}$ & $\begin{array}{l}\text { recurrent rate }(\%) \text { and occurred } \\
\text { timing after treatment (month) }\end{array}$ & $\begin{array}{l}\text { MGMT } \\
\text { correlations }\end{array}$ & $\begin{array}{c}\text { case } \\
\text { numbers } \\
\text { (cancer) }\end{array}$ & $\begin{array}{l}\text { ref, year } \\
\text { [ref no] }\end{array}$ \\
\hline $\mathrm{CR} / \mathrm{PR} ; 51 \%$ & $2-24$ & 16 & $46 \%$; after 5 months & No & $43(14)$ & Lasolle (2) \\
\hline PR/CR;29\%, SD;58\%, PD14\% & $2-13$ & ns & ns & No & $7(2)$ & Bush (3) \\
\hline CR/PR/SD; 38\% & $3-24$ & ns & ns & No & $8(5)$ & Raverot (4) \\
\hline CR/PR;33\%, SD;33\%, PD;33\% & $3-12$ & 22.5 & $33 \%$; after 6 months & Yes & $6(1)$ & Losa (5) \\
\hline CR/PR;31\%, SD;15\%, PD;54\% & $3-24$ & ns & 46\%; after 10.5 months & No & $13(10)$ & Hirohata (6) \\
\hline CR/PR;33\% & $3-6$ & ns & $\mathrm{ns}$ & ns & $6(1)$ & Bruno $(7)$ \\
\hline CR/PR;43\% & $1-23$ & 32.5 & $33 \%$ & Yes & $21(8)$ & Bengtsson (8) \\
\hline PR;40\%, SD;20\%, PD;40\% & $3-24$ & ns & ns & ns & $5(0)$ & Ceccato (9) \\
\hline CR/PR;36\%, SD;45\%, PD;19\% & $3-12$ & 43 & $52 \% ;$ after cessation & No & $31(6)$ & Losa (10) \\
\hline CR;6\%, PR;31\%, SD;33\%, PD;30\% & $1-36$ & 21 & $38 \%$; after 12 months & Yes & $166(40)$ & McCormack (11) \\
\hline $\begin{array}{l}\text { TMZ-based therapy was associated with the } \\
\text { longest PFS (71\%) and long disease control }\end{array}$ & -12 & 28 & $62 \%$ & ns & $13(13)$ & Santos (12) \\
\hline CR/PR;20\%, SD;17\%, PD;63\% & $1-26$ & 32 & $63 \%$; after 16 months & No & $47(13)$ & Elbelt (13) \\
\hline
\end{tabular}

ns, not stated; CR complete response; PR, partial response; SD, stable disease; PD, progressive disease; PFS, progression free survival.

TMZ is not recommended if an initial treatment fails to control disease progression. One of the reasons for such a relapse might be related to TMZ-induced hypermutations in genes such as $M S H 6, C D K N 2 A / B$, and $P I K 3 C A$, which can be associated with TMZ resistance (29).

Several biomarkers that may predict response to TMZ have been identified. One such marker is O6-methylguanine DNA methyltransferase (MGMT), a DNA-repair enzyme, which counteracts TMZ-induced DNA damage (44). The expression of MGMT seems to correlate with response of a tumor to the TMZ therapy. A number of studies indicate an association between low expression levels of MGMT (determined by immunostaining) and better treatment response to TMZ $(1,5,8,11,45-51)$. However, this association was not observed in several other studies $(2-4,6,10,13)$ (Table 1). This discrepancy could be, at least in part, derived from a lack of standardized scoring systems for MGMT immunostaining. In addition, the expression level of MGMT may increase during TMZ therapy (45), which could affect interpretation of MGMT expression. At present, the expression of MGMT is still considered a predictive marker for TMZ response. Another biomarker is MutS Homolog 6 (MSH6), a DNA mismatch repair protein. Mutations in the MSH6 gene in glioblastoma are known to be associated with TMZ resistance (52). One study showed that expression of MSH6 was positively correlated with pituitary tumor regression following treatment with TMZ (6); however, a follow-up study failed to confirm this correlation (8).

\section{TMZ-BASED COMBINATION THERAPIES: CAPECITABINE (PRO-DRUG OF 5-FLUOROURACIL) + TEMOZOLOMIDE (CAPTEM)}

Capecitabine (orally administered systemic pro-drug of 5-Fluorouracil) is an antimetabolite that incorporates 5-fluorodeoxyuridine triphosphate into genomic DNA. Capecitabine causes attenuation of MGMT DNA repair activity through thymidylate synthase inhibition and reduction of the thymidine level, which enhances the apoptotic effect of TMZ $(53,54)$. CAPTEM is a novel combination of capecitabine and TMZ. Two in vitro experiments investigating antitumor effects of CAPTEM have been reported. One study in human carcinoid cell lines showed synergistic cytotoxicity when 5-fluorouracil (5-FU) exposure was preceded by TMZ (55). The other study, conducted by the authors of this review, used mouse corticotroph tumor cells to demonstrate that 5-FU treatment in combination with TMZ had an additive effect both in decreasing cell viability and reducing the amount of $\mathrm{ACTH}$ released by the tumor cells in the culture medium (15).

The clinical protocol of CAPTEM consists of oral capecitabine $1,500 \mathrm{mg} / \mathrm{m}^{2} /$ day (maximum daily dose of 2,500 mg on days 1 through 14 divided into two doses) and TMZ 150 to $200 \mathrm{mg} / \mathrm{m}^{2} /$ day (oral divided into two doses) given on days 10 through 14 . This 2 -week regimen is followed by 2 weeks offtreatment [Figure 1B (14)]. Data obtained from in vitro experiments support the efficacy of two separate TMZ treatments (56). Specifically, the first treatment causes partial reduction of MGMT activities, whereas the second treatment is responsible for the methylation of guanine residues once repair activity by MGMT has been attenuated (53).

CAPTEM is generally well tolerated; among 13 patients with aggressive pituitary tumors/carcinomas, 12 patients were able to tolerate the treatment without discontinuing therapies (Table 2). Three patients developed thrombocytopenia but only one of these patients had to discontinue CAPTEM due to thrombocytopenia and poor tolerance (29). Another patient developed lymphopenia without discontinuing treatment, and one case reduced to $75 \%$ of the maximal dose of CAPTEM due to nausea (15). The first reported use of CAPTEM for pituitary tumors was for an aggressive corticotroph pituitary carcinoma in 2011 (57). To date, 13 TMZ naïve cases of aggressive pituitary tumors/carcinomas treated with CAPTEM (TMZ naïve cases) have been reported, of which seven were carcinomas (7/13) and 11 were ACTH positive $(11 / 13)(11,14,15,26,29,57-59)$ (Table 2). Clinical or radiological improvements were observed in 11 out of 13 cases, in which tumor progression stopped for up to 54 months. In seven patients with 
TABLE 2 | Published cases of Capecitabine (pro-drug of 5-Fluorouracil) + Temozolomide (CAPTEM) (TMZ naïve) for aggressive pituitary tumors and carcinomas.

\begin{tabular}{|c|c|c|c|c|c|c|c|}
\hline $\begin{array}{l}\text { Response in tumor growth/PFS } \\
\text { (month) }\end{array}$ & $\begin{array}{l}\text { CAPTEM } \\
\text { (cycles) }\end{array}$ & $\begin{array}{l}\text { Tumor } \\
\text { subtype }\end{array}$ & Pathology & $\begin{array}{l}\text { Previous } \\
\text { treatment }\end{array}$ & Side effects & $\begin{array}{l}\text { Age/ } \\
\text { sex }\end{array}$ & Ref, year [ref no] \\
\hline PR, PFS (22) & 12 & ACTH & MGMT: ns & ns & ns & $44 / \mathrm{M}$ & McCormack (11) \\
\hline PR, PFS (6) & 6 & $\mathrm{ACTH}$ & MGMT: ns & ns & ns & $49 / \mathrm{M}$ & McCormack (11) \\
\hline $\mathrm{PD}$ & 18 & PRL-CA & MGMT: ns & $\mathrm{ns}$ & $\mathrm{ns}$ & $38 / \mathrm{M}$ & McCormack (11) \\
\hline SD, PFS $(54+)$ & 30 & ACTH & $\begin{array}{l}\text { MGMT:low, } \\
\text { Ki-67: <5\% }\end{array}$ & $\begin{array}{l}\text { TSS, BAD, } \\
\text { RT }\end{array}$ & thrombocytopenia & $50 / \mathrm{M}$ & Zacharia (14) \\
\hline CR, PFS (32+) & 32 & $\mathrm{ACTH}$ & $\begin{array}{l}\text { MGMT:low, } \\
\text { Ki-67: } 5 \%\end{array}$ & TSS, RT & lymphopenia & $46 / F$ & Zacharia (14) \\
\hline CR, PFS (45+) & 45 & Silent ACTH & $\begin{array}{l}\text { MGMT:low, } \\
\text { Ki-67: }<5 \%\end{array}$ & TSS, RT & none & $44 / \mathrm{M}$ & Zacharia (14) \\
\hline PR, extra-axial met & $\begin{array}{c}12 \\
\text { off } 27 \text { mon, } \\
12 \text { ongoing }\end{array}$ & $\begin{array}{l}\text { Silent ACTH- } \\
\text { CA }\end{array}$ & $\begin{array}{l}\text { MGMT: low, } \\
\text { Ki-67: } 1-5 \%\end{array}$ & TSS, RT & $\begin{array}{l}\text { mild constipation } \\
12\end{array}$ & $54 / \mathrm{M}$ & Nakano-Tateno (15) \\
\hline PR, PFS (34+) & 12 & $\mathrm{ACTH}$ & $\begin{array}{l}\text { MGMT: low, } \\
\text { Ki-67: <1\% }\end{array}$ & TSS, RT & nausea & $48 / \mathrm{M}$ & Nakano-Tateno (15) \\
\hline PD & 3 & PIT1-CA & $\begin{array}{l}\text { MGMT: ns, } \\
\text { Ki-67: } 15 \%\end{array}$ & TSS, RT & ns & $23 / F$ & Alshaikh (26) \\
\hline PR for 24 mo, then liver met & 4 & $\mathrm{ACTH}-\mathrm{CA}$ & MGMT+ (liver) & $\begin{array}{l}\text { TSS, BAD, } \\
\text { RT) }\end{array}$ & thrombocytopenia & $35 / F$ & $\operatorname{Lin}(29)$ \\
\hline PR, PFS (5.5) & 4 & $\mathrm{ACTH}-\mathrm{CA}$ & $\begin{array}{l}\text { MGMT: ns, } \\
\text { Ki-67:31\% }\end{array}$ & $\begin{array}{l}\text { TSS, BAD, } \\
\text { RT }\end{array}$ & none & $50 / \mathrm{M}$ & Thearle (57) \\
\hline PR,spine and pelvic met & 8 & $\mathrm{ACTH}-\mathrm{CA}$ & $\begin{array}{l}\text { MGMT:ns, Ki-67:19-50\%, } \\
\text { p53+ }\end{array}$ & TSS, RT & thrombocytopenia & $46 / F$ & Donovan (58) \\
\hline SD, PFS (8) & 8 & $\mathrm{ACTH}-\mathrm{CA}$ & $\begin{array}{l}\text { MGMT:ns, } \\
\text { Ki-67: 4-15\% }\end{array}$ & TSS, RT & ns & $49 / F$ & Joehlin-Price (59) \\
\hline
\end{tabular}

ns, not stated; CR, complete response; PR, partial response; SD, stable disease; PD, progressive disease; PFS, progression free survival; CA, carcinoma TSS, transsphenoidal surgery; $B A D$, bilateral adrenalectomy; $R T$, external beam radiotherapy; mo, months; met, metastasis.

carcinomas (five ACTH positive, one PRL positive, and one PIT-1 positive), five patients (71\%) initially showed partial reduction of tumor size in response to CAPTEM treatment and no tumor progression for as long as 39 months. These reports include two cases of pituitary tumors treated with CAPTEM: one is a corticotroph carcinoma and the other is an aggressive corticotroph tumor (15). Both patients had undergone previous surgical and radiologic therapies. The first patient with corticotroph carcinoma started to receive the CAPTEM treatment after developing leptomeningeal spread. Twelve cycles of the treatment resulted in tumor control associated with improvement of clinical and radiological tumor size reduction for 39 months. The patient restarted CAPTEM after recurrence of the tumor, and is currently under treatment. The second patient, with an aggressive corticotroph tumor, was treated with 12 cycles of CAPTEM, which led to tumor shrinkage with no tumor regrowth 22 months after cessation of therapy. As for the side effects of CAPTEM, the second patient had nausea, which was manageable by reducing the dose of CAPTEM to $75 \%$ of the maximal after the $6^{\text {th }}$ cycle.

CAPTEM has been used in TMZ resistant cases as well. CAPTEM treatment followed by TMZ monotherapy (TMZ resistant cases) has been reported in eight cases (three ACTH secreting carcinomas, two PRL secreting carcinomas, one null-cell carcinoma, and two cases not stated) $(8,10-12,42)$. However, the outcome was unfavorable in seven cases $(88 \%)$, and only one (nullcell carcinoma) had a partial regression of carcinoma (42). From this limited dataset, CAPTEM seems to be more effective in TMZ naive cases compared to those with TMZ resistance. Unlike TMZ monotherapy, it is unknown whether MGMT expression in tumors can be a predictive marker for response to CAPTEM. In six aggressive pituitary tumors treated with CAPTEM, five cases (83\%) showed low MGMT expression levels, and one case had positive expression in the liver metastasis $(14,15,29,57)$. The outcome of these low MGMT cases varies, including cases of complete regression, partial regression, and stabilization of the tumor. Further studies are required to determine the role of MGMT expression in predicting response to CAPTEM therapy.

Other than CAPTEM, there are a few case reports of TMZ in combination with other therapeutic agents. Among them are the combinations of TMZ with VEGF-targeted therapy (Bevacizumab or Apatanib) (60-62) and a somatostatin receptor ligand (Pasireotide) $(9,63)$. In a survey by the European Society of Endocrinology, 1 case treated with TMZ in combination with bevacizumab achieved a partial tumor regression, 1 case with thalidomide showed no progression of the disease, and 1 case with Carmustine showed progressive disease (PD) (11). Although a prospective clinical trial is required to determine whether the treatment with CAPTEM is superior to the treatment with TMZ alone, CAPTEM appears to be a promising treatment option for aggressive pituitary tumors and carcinomas based on several case reports and our experimental data.

\section{PEPTIDE RECEPTOR RADIONUCLIDE THERAPY (PRRT)}

Peptide Receptor Radionuclide Therapy (PRRT) is a form of targeted therapy that utilizes the delivery of radionuclide-bound 
somatostatin agonists to pituitary tumors expressing somatostatin receptors (SSTRs). PRRT has successfully treated neuroendocrine tumors, due to their high levels of SSTR expression (64-66). The use of PRRT for pituitary tumors was introduced after its success in treating neuroendocrine tumors (17). Radionuclides such as Yttrium 90 (Y-90), Lutetium 177 (Lu-177), and Indium-111 (In-111) are combined with peptides or somatostatin agonists (e.g., DOTATOC, DOTATATE) to deliver radiation to tumor cells. Because this is a targeted therapy, the risk of the systemic adverse effects is lower than conventional radiation therapy $(18,38)$.

There is still limited evidence whether PRRT is effective in the management of aggressive pituitary adenomas or carcinomas (8, 16-24) (Table 3). From the review of English literature between the years of 2012 and 2020, we found a total of 15 cases describing PRRT treatment in aggressive pituitary tumors (11 cases) and carcinomas (four cases). The treatment protocols used (dose, type of radionuclide and peptide, timing of radionuclide delivery) and measured outcomes across these cases vary greatly and are summarized in Table 3. Broadly, regarding tumor size, among 15 reported cases, six cases (43\%) responded to PRRT. Decrease in hormone levels was reported in only three cases (20\%, Table 3 ).
In general, PRRT treatment is tolerated well without major side effects. In a study of 30 patients with advanced cancers (mostly neuroendocrine tumors) receiving [111In-DTPA ${ }^{0}$ ] octreotide up to a high cumulative dose of $75 \mathrm{Gbq}$, no major side effects were noted. Transient reduction in platelets and leukocytes can occur (67). From our review of 15 cases of aggressive pituitary tumors treated with PRRT, one patient developed transient grade 2 thrombocytopenia (20).

There is no clear evidence as to whether dosage or type of radionucleotide affects outcomes (23). From our review of 15 cases, total average radiation dose seems similar, with an average of $15.4 \mathrm{GBq}$ in responders versus an average dose of $14.5 \mathrm{GBq}$ in non-responders. However, dosages varied widely in both groups (from $0.4 \mathrm{GBq}$ to $37 \mathrm{GBq}$ ), therefore it is difficult to assess whether dosage affects outcomes or not. It is also unknown whether the pre-treatment radioisotope uptake scan corresponds with treatment outcomes $(18,22,23)$. In well-differentiated neuroendocrine tumors and medullary thyroid cancers, the total amount of pre-treatment radioisotope uptake did not reflect prognosis well, but heterogeneous uptake may correspond with poor prognosis after PRRT treatment $(68,69)$. In pituitary tumors, dosimetry analysis was reported in only

TABLE 3 | Published cases of peptide receptor radionuclide therapy (PRRT) for pituitary tumors and carcinomas.

\begin{tabular}{|c|c|c|c|c|c|c|c|c|c|}
\hline $\begin{array}{l}\text { Response in tumor } \\
\text { growth }\end{array}$ & $\begin{array}{l}\text { Hormone } \\
\text { reduction }\end{array}$ & $\begin{array}{c}\text { PFS } \\
\text { (month) }\end{array}$ & $\begin{array}{l}\text { Tumor } \\
\text { subtype }\end{array}$ & $\begin{array}{l}\text { Initial tumor } \\
\text { volume }(\mathrm{ml})\end{array}$ & $\begin{array}{l}\text { Total radiation dose/ } \\
\text { (number of cycles) }\end{array}$ & $\begin{array}{l}\text { Type of } \\
\text { radionuclide }\end{array}$ & $\begin{array}{l}\text { Previous } \\
\text { treatment }\end{array}$ & $\begin{array}{l}\text { Age/ } \\
\text { sex }\end{array}$ & $\begin{array}{l}\text { Ref, year } \\
\text { [ref no] }\end{array}$ \\
\hline$n / a$ & ns & 5 & NFPA & ns & ns & $\begin{array}{l}\text { 177Lu- } \\
\text { DOTATE }\end{array}$ & $\mathrm{TMZ}$ & $59 / F$ & Bengtsson (8) \\
\hline PD & ns & 8 & $\mathrm{GH}-\mathrm{CA}$ & ns & ns & 9OY-DOTATE & $\mathrm{TMZ}$ & $\begin{array}{l}46 / \\
M\end{array}$ & Bengtsson (8) \\
\hline PD & ns & 8 & PRL & ns & ns & $\begin{array}{l}\text { 68Gallium } \\
\text { DOTATE }\end{array}$ & $\mathrm{TMZ}$ & $\begin{array}{l}23 / \\
M\end{array}$ & Bengtsson (8) \\
\hline $\mathrm{n} / \mathrm{a}$ & ns & ns & $\begin{array}{l}\text { NFPA- } \\
\text { CA }\end{array}$ & $4.1 \mathrm{ml}$ & 0.15 GBq (one dose) & $\begin{array}{l}\text { 177Lu- } \\
\text { DOTATE }\end{array}$ & none & $71 / F$ & Kumar (16) \\
\hline $\begin{array}{l}\text { decreased } 95 \% \text { over } \\
8 \text { years }\end{array}$ & PRL decreased & ns & PRL & $63 \mathrm{~mL}$ & 37 GBq (5) & $\begin{array}{l}\text { 111ln-DTPA- } \\
\text { octreotide }\end{array}$ & $\begin{array}{l}\text { TSS, RT, } \\
\text { octreotide }\end{array}$ & $58 / F$ & Baldari (17) \\
\hline SD over 8 years & ns & 96 & NFPA & ns & $0.6 \mathrm{GBq}(3)$ & $\begin{array}{l}\text { 177Lu- } \\
\text { DOTATE }\end{array}$ & TSS & $\begin{array}{l}55 / \\
M\end{array}$ & Komor (18) \\
\hline $\begin{array}{l}\text { Decreased } 60.5 \% \\
\text { over } 12 \text { months }\end{array}$ & IGF decreased & 12 & $\mathrm{GH}$ & $23.1 \mathrm{ml}$ & $\begin{array}{l}0.4 \mathrm{GBq}(0.1 \mathrm{GBq} \text { every } \\
3 \mathrm{mo})\end{array}$ & 9OY-DOTATE & $\begin{array}{l}\text { TSS, RT, } \\
\text { octreotide, } \\
\text { lanreotide }\end{array}$ & $\begin{array}{l}26 / \\
M\end{array}$ & $\begin{array}{l}\text { Waligórska- } \\
\text { Stachura (19) }\end{array}$ \\
\hline $\begin{array}{l}\text { Pituitary: SD, met } \\
\text { volume: decrease }\end{array}$ & ns & 40 & $\begin{array}{l}\text { NFPA- } \\
\text { CA }\end{array}$ & ns & 29.6 GBq (one dose) & $\begin{array}{l}\text { 177Lu- } \\
\text { DOTATE }\end{array}$ & TSS, RT & $\begin{array}{l}63 / \\
M\end{array}$ & Maclean (20) \\
\hline $\mathrm{PD}$ & ns & ns & $\mathrm{GH} / \mathrm{PRL}$ & ns & 15.3 GBq (2) & $\begin{array}{l}\text { 177Lu- } \\
\text { DOTATE }\end{array}$ & $\begin{array}{l}\text { TSS, RT, TMZ, } \\
\text { lanreotide }\end{array}$ & $\begin{array}{l}42 / \\
M\end{array}$ & Maclean (20) \\
\hline PD & ns & ns & ACTH & ns & ns (one dose) & $\begin{array}{l}\text { 177Lu- } \\
\text { DOTATE }\end{array}$ & TSS, RT, TMZ & $\begin{array}{l}32 / \\
M\end{array}$ & Maclean (20) \\
\hline $\begin{array}{l}\text { SD over } 1 \text { year, then } \\
\text { pituitary apoplexy }\end{array}$ & $\begin{array}{l}\text { GH decreased, IGF } \\
\text { persistently high }\end{array}$ & 12 & $\mathrm{GH}$ & $31.8 \mathrm{ml}$ & $22.2 \mathrm{GBq}(3)$ & $\begin{array}{l}\text { 177Lu- } \\
\text { DOTATE }\end{array}$ & surgical attempt & $\begin{array}{l}48 / \\
M\end{array}$ & Assadi (21) \\
\hline SD over 4 years & ns & 48 & $\begin{array}{l}\text { NFPA- } \\
\text { CA }\end{array}$ & ns & $22.2 \mathrm{GBq}(3)$ & $\begin{array}{l}\text { 177Lu- } \\
\text { DOTATE }\end{array}$ & TSS, RT & $\begin{array}{l}68 / \\
M\end{array}$ & Novruzov (22) \\
\hline PD & ns & ns & $\mathrm{PRL}$ & $20.2 \mathrm{ml}$ & 12.6 GBq (2) & $\begin{array}{l}\text { 177Lu- } \\
\text { DOTATOC }\end{array}$ & TSS, RT, TMZ & $\begin{array}{l}54 / \\
M\end{array}$ & Giuffrida (23) \\
\hline PD & ns & ns & NFPA & $7.7 \mathrm{~mL}$ & $29.8 \mathrm{GBq}(5)$ & $\begin{array}{l}\text { 177Lu- } \\
\text { DOTATOC }\end{array}$ & TSS, RT, TMZ & $53 / F$ & Giuffrida (23) \\
\hline PD & ns & $<12$ & $\begin{array}{l}\mathrm{ACTH}- \\
\mathrm{CA}\end{array}$ & ns & $0.2 \mathrm{GBq}$ (one dose) & $\begin{array}{l}90 Y- \\
\text { DOTATOC }\end{array}$ & TSS, RT & $16 / F$ & Kovács (24) \\
\hline
\end{tabular}

ns, not stated; NFPA, non-functioning pituitary adenoma; CA, carcinoma; TSS, transsphenoidal surgery; RT, radiation therapy; CR, complete response; PR, partial response; SD, stable disease; PD, progressive disease; PFS, progression free survival; mo, months. 
1 case, which showed a heterogeneous uptake pattern with progressed disease (20).

It is of interest to know the difference in efficacy between somatostatin analog (SSA) therapy and PRRT, however, at this point, there is no direct comparison study. At this stage, PRRT is a treatment option for aggressive pituitary tumors that express SSTR and are resistant to other therapies. The 2018 guidelines of the European Society of Endocrinology listed PRRT as an alternative treatment option for aggressive pituitary tumors (1). Taken together, current evidence does not suggest that PRRT is an impressively effective treatment for aggressive pituitary tumors, however it is still premature to conclude that PRRT is not an important treatment strategy since half of the reported cases were TMZ resistant which are usually difficult to control disease progressions.

\section{mTOR INHIBITORS}

The phosphatidylinositol 3-kinase/mammalian target of rapamycin (mTOR) pathway is involved in the regulation of survival, growth, protein synthesis, and cellular metabolism (7073). Everolimus (EVE) is an orally active mTOR inhibitor FDAapproved to treat neuroendocrine tumors. EVE forms a complex with mTORC1, affecting downstream cellular activities, and causes cell cycle arrest and protein synthesis inhibition. Many studies have shown that EVE is effective in human pituitary tumor cultures and murine cell lines in vitro (74-77). It is also effective in vivo in intracranial GH4 cell xenograft mouse models and reduced transplanted tumor cell viability and proliferation (78). Moreover, EVE synergized with SSAs, such as octreotide or pasireotide, and exhibited anti-proliferative effects in primary human pituitary tumor cells $(79,80)$.

Although EVE has been widely used in the management of pancreatic and other neuroendocrine neoplasms, there are only seven published cases of pituitary tumors treated with EVE combination therapy (three ACTH secreting carcinomas, one PRL secreting adenoma, and three not stated) $(11,25-27,58)$ (Table 4). Of note, five out of seven $(71 \%)$ cases had disease progression, and tumors in all the failed cases were TMZ resistant. The protocol used for EVE treatment is variable. The reported dose of EVE is 5 to 10 mg daily for several months, either as a monotherapy or in combination with other therapies. Common side effects include stomatitis, rash, fatigue, diarrhea, infections, anemia, and hyperglycemia (25). Initial reduction in hormone secretion was observed in only one out of seven patients treated with EVE (25). A patient with a PRL secreting tumor treated with EVE 10mg + octreotide showed decreased PRL levels (454 ng/ml to $253 \mathrm{ng} / \mathrm{ml}$; $55 \%$ reduction) after an initial 3 months of EVE therapy; however, PRL level gradually increased to its previous level by 5 months following initiation of EVE therapy (25). Among the seven published cases, only two out of seven cases (29\%) reported no progression of tumor growth: one corticotroph carcinoma treated with EVE $(7.5 \mathrm{mg})+$ Capecitabine followed by EVE (7.5-10 mg) + RT showed no increase in tumor volume for 5 months (58), and an aggressive PRL secreting tumor treated with EVE 10mg + octreotide showed stable tumor volume for 12 months (25). Currently, there is not a sufficient number of cases with EVE treatment for pituitary tumors to determine its effectiveness. In addition, the complexity of the reported cases may have biased the outcomes of EVE treatment. For example, three out of seven reported cases were pituitary carcinomas and six out of seven EVE treated cases were TMZ refractory cases. Further work will be required to define the role and effectiveness of EVE in management of pituitary tumors.

\section{IMMUNOTHERAPY}

Immune checkpoint inhibitors upregulate the body's immune response to fight against malignancy and have been used to treat melanomas, lung cancers, renal cancers and Hodgkin lymphomas (81). Pembrolizumab (PEM) and nivolumab (NIV) are checkpoint inhibitors that inhibit programmed cell death 1 (PD-1), which is a transmembrane protein expressed on immune cells that inhibits Tcell destruction of tumor cells. Ipilimumab (IPI) is a checkpoint inhibitor that inhibits the action of Cytotoxic T-lymphocyteassociated protein 4 (CTLA-4), which downregulates immune

TABLE 4 | Published cases of Everolimus (EVE) treatments for pituitary tumors and carcinomas.

\begin{tabular}{|c|c|c|c|c|c|c|c|}
\hline Response in tumor growth & EVE treatment & $\begin{array}{l}\text { Duration } \\
\text { (month) }\end{array}$ & $\begin{array}{l}\text { Tumor } \\
\text { subtype }\end{array}$ & Pathology & Previous treatments & $\begin{array}{l}\text { Age/ } \\
\text { sex }\end{array}$ & $\begin{array}{l}\text { Ref, year } \\
\text { [ref no] }\end{array}$ \\
\hline PD & EVE & ns & ns & ns & $\mathrm{TMZ}$ & ns & $\begin{array}{l}\text { McCormack } \\
(11)\end{array}$ \\
\hline PD & EVE & ns & ns & ns & $\mathrm{TMZ}$ & ns & McCormack \\
\hline PD & EVE & ns & ns & ns & $\mathrm{TMZ}$ & ns & $\begin{array}{l}\text { McCormack } \\
(11)\end{array}$ \\
\hline $\begin{array}{l}\text { tumor size: SD for } 12+\text { mon, hormone } \\
\text { reduction: PR for } 8 \text { mon }\end{array}$ & $\mathrm{EVE}+\mathrm{OCT}$ & $12+$ & $P R L$ & $\begin{array}{l}\text { Ki-67: } 30 \% \\
\text { p53+ }\end{array}$ & Surgery, RT, CAB & $62 / \mathrm{M}$ & Zhang (25) \\
\hline $\mathrm{PD}$ & EVE & ns & $\mathrm{ACTH}-\mathrm{CA}$ & Ki-67: 10\% & Surgery, BAD, RT, TMZ & $49 / F$ & Alshaikh (26) \\
\hline PD & $\mathrm{EVE}+\mathrm{OCT}$ & 1 & ACTH-CA & $\begin{array}{l}\text { Ki-67: low, } \\
\text { mitoses+ }\end{array}$ & $\mathrm{TMZ}$ & $45 / \mathrm{M}$ & $\begin{array}{l}\text { Jouanneau } \\
(27)\end{array}$ \\
\hline SD for 5 mon then PD & $\begin{array}{l}\text { EVE+paliative RT, } \\
\text { EVE+Capecitabine }\end{array}$ & 8 & ACTH-CA & $\begin{array}{l}\text { Ki-67: 19- } \\
50 \%, \text { p53+ }\end{array}$ & $\begin{array}{l}\text { Surgery, BAD, RT, } \\
\text { CAB, CAPTEM }\end{array}$ & $46 / F$ & Donovan (58) \\
\hline
\end{tabular}

ns, not stated; $C A$, carcinoma; $B A D$, bilateral adrenalectomy; $R T$, radiation therapy; $S D$, stable disease; $P D$, progressive disease. 
response (82). CTLA-4 and PD-1 are both expressed in pituitary adenomas (83-85). This is thought to be a mechanism by which immunotherapy can contribute to the treatment of pituitary tumors. However, the use of checkpoint inhibitors is associated with several adverse effects, including hypophysitis (86). For example, singleagent anti-PD-1/PD-L1 monoclonal antibody therapy is associated with incidence rate of hypophysitis between $1 \%$ to $6 \%$ (87). Combination of IPI (CTLA-4) plus NIV (PD-1) is associated with hypophysitis rate as high as $7.7 \%$ to 11.7 percent $(88,89)$. Other adverse effects by ICIs include thyroiditis (1\%-6\%) (90), primary adrenal insufficiency (0.7\%) (91), dermatitis (34\%-39\%) (92), and hepatotoxicity (5\%-10\% with PD-1) (93).

Thus far, checkpoint inhibitors have been used to treat pituitary adenomas in five cases $(29-31,94)$ (Table 5). Of these five cases, three cases were ACTH-producing carcinomas, one case was an ACTH-producing adenoma, and one case was a prolactinoma. All ACTH-producing carcinoma cases received a combination of IPI and NIV and showed decreased to stable sizes of pituitary carcinomas, ACTH levels, and the liver metastatic volume in two cases $(29,30,94)$. However, one of these positively responding cases of pituitary carcinoma recurred over 1 year. Of note, two other cases of non-carcinomas [ACTH-producing adenoma (treated with PEM) and prolactinoma (treated with IPI and NIV)] had disease progression despite immunotherapy $(31,94)$.

\section{CONVENTIONAL THERAPIES}

\section{DAs Based Combination Therapies for Aggressive Prolactinomas}

Although the dopamine agonists (DAs) (bromocriptine (BRC) and cabergoline $(\mathrm{CAB})$ ) are established first-line treatments for prolactinomas (95), DA resistance in prolactinomas occurs in $20 \%-30 \%$ of patients treated with BRC and $10 \%$ of patients treated with $\mathrm{CAB}$ (96). Possible mechanisms include decreased expression of dopamine receptor D2 (D2R), changes upstream or downstream of $\mathrm{D} 2 \mathrm{Rs}$ signaling, increased angiogenic markers, and disruptions in the TGF- $\beta 1$ pathway (97). It has been reported that higher dose of $\mathrm{CAB}$ therapy is successful in treating BRC resistant prolactinomas (96). Patients are generally able to tolerate high doses of DAs (98), but periodic echocardiogram may be required for prolonged high-dose use since cumulative dosage increases the risk of valvular heart disease (99). In addition to monotherapy, DA therapies in combination with tamoxifen (TAM) or octreotide (OCT) have been reported to treat DA-resistant prolactinomas with various response rates, summarized in Table 6 (100-105). Metformin was also used in combination therapies (103). A case series with DAs and metformin over 8-14 months have noted both PRL normalization and significant tumor reduction (103).

\section{DAs Based Therapies for Recurrent or Residual NFPAs}

$\mathrm{CAB}$ monotherapy has been also used for recurrent or residual NFPAs (187 cases in six studies) (106-111). In these studies, in $33 \%$ of patients, CAB monotherapy resulted in more than $25 \%$ of tumor volume reduction or reduction of tumor size less than $2 \mathrm{~mm}$ in diameter, although the tumor reduction rate in these studies varies. The average dose of CAB was $2.95 \mathrm{mg} /$ week and the average treatment duration was 8 months. The largest study, including 79 patients treated with DAs, demonstrated 35\% reduction of tumor size on average when used against recurrent or residual NFPAs (111). It remains to be determined whether combinations of DAs with other drugs will be effective against refractory NFPAs.

\section{SSA Based Combination Therapies for SSA-Resistant Acromegaly}

OCT resistance is estimated to occur in approximately $30 \%$ of $\mathrm{GH}$-secreting adenomas and is thought to be mediated by

TABLE 5 | Published cases of Immunotherapy treatments for pituitary tumors and carcinomas.

\begin{tabular}{|c|c|c|c|c|c|c|c|}
\hline Response in tumor growth & Hormone reduction & Treatment & Tumor subtype & Pathology & $\begin{array}{l}\text { Previous } \\
\text { treatment }\end{array}$ & Age/sex & $\begin{array}{l}\text { Ref, year } \\
\text { [ref no] }\end{array}$ \\
\hline $\begin{array}{l}\text { intracranial: } \\
\text { decreased by } 59 \% \text {, liver met: } \\
\text { decreased by } 98 \% \text {. SD after } 6 \\
\text { months }\end{array}$ & $\begin{array}{l}\text { Decreased ACTH by } \\
100 \%\end{array}$ & $\begin{array}{l}\text { IPI and NIV } 5 \text { cycles } \\
\text { followed by NIV only }\end{array}$ & $\mathrm{ACTH}-\mathrm{CA}$ & $\begin{array}{l}\text { Liver: mitotic } \\
\text { index } 50 \% \\
\text { PDL-1 }<1 \%\end{array}$ & $\begin{array}{l}\text { TSS, RT } \\
\text { BAD, TMZ }\end{array}$ & $41 / F$ & $\operatorname{Lin}(29)$ \\
\hline SD & $\begin{array}{l}\text { Decreased ACTH by } \\
30 \% \text {, am cortisol by } \\
64 \% \text {, UFC by } 74 \%\end{array}$ & $\begin{array}{l}\text { IPI and NIV } 4 \text { cycles, then } \\
\text { NIV maintenance and } \\
\text { ketoconazole }\end{array}$ & $\mathrm{ACTH}-\mathrm{CA}$ & Ki-67:<1\% & $\begin{array}{l}\text { TSS, RT, } \\
\text { TMZ }\end{array}$ & $41 / \mathrm{M}$ & Sol (30) \\
\hline PD & $\mathrm{PD}$ & PEM 4 cycles & ACTH & $\begin{array}{l}\text { MIB }>3 \% \\
\text { PDL-1 negative }\end{array}$ & $\begin{array}{l}\text { TSS, RT, } \\
\text { TMZ }\end{array}$ & $66 / M$ & Caccese (31) \\
\hline $\begin{array}{l}\text { Pituitary: decreased by } 15 \% \text {, liver } \\
\text { met: decreased by } 57-69 \% . \text { PD } \\
\text { after } 12 \text { months }\end{array}$ & $\begin{array}{l}\text { Decreased ACTH by } \\
>93 \% \text { then PD }\end{array}$ & $\begin{array}{l}\text { IPI and NIV } 5 \text { cycles } \\
\text { followed by NIV } 21 \text { cycles }\end{array}$ & $\mathrm{ACTH}-\mathrm{CA}$ & $\begin{array}{l}\text { Ki-67: } 5 \% \\
\text { Liver: } \mathrm{Ki}-67 \\
\text { 10\%, PDL-1 } \\
\text { negative }\end{array}$ & $\begin{array}{l}\text { TSS, RT, } \\
\text { TMZ }\end{array}$ & $60 / \mathrm{F}$ & Duhamel (94) \\
\hline PD & PD & IPI and NIV 2 cycles & PRL & Ki-67: 25\% & $\begin{array}{l}\text { TSS, RT, } \\
\text { TMZ }\end{array}$ & $68 / \mathrm{M}$ & Duhamel (94) \\
\hline
\end{tabular}

NFPA, non-functioning pituitary adenoma; CA, carcinoma; TSS, transsphenoidal surgery; RT, radiation therapy; BAD, bilateral adrenalectomy; PEM, pembrolizumab; IPI, ipilimumab; NIV, nivolumab; HR, hormonal response; SD, stable disease; PD, progressive disease; UFC, urinary free cortisol. 
TABLE 6 | Summary of conventional therapies for aggressive prolactinomas, Cushing's disease, and acromegaly and non-functional pituitary adenomas.

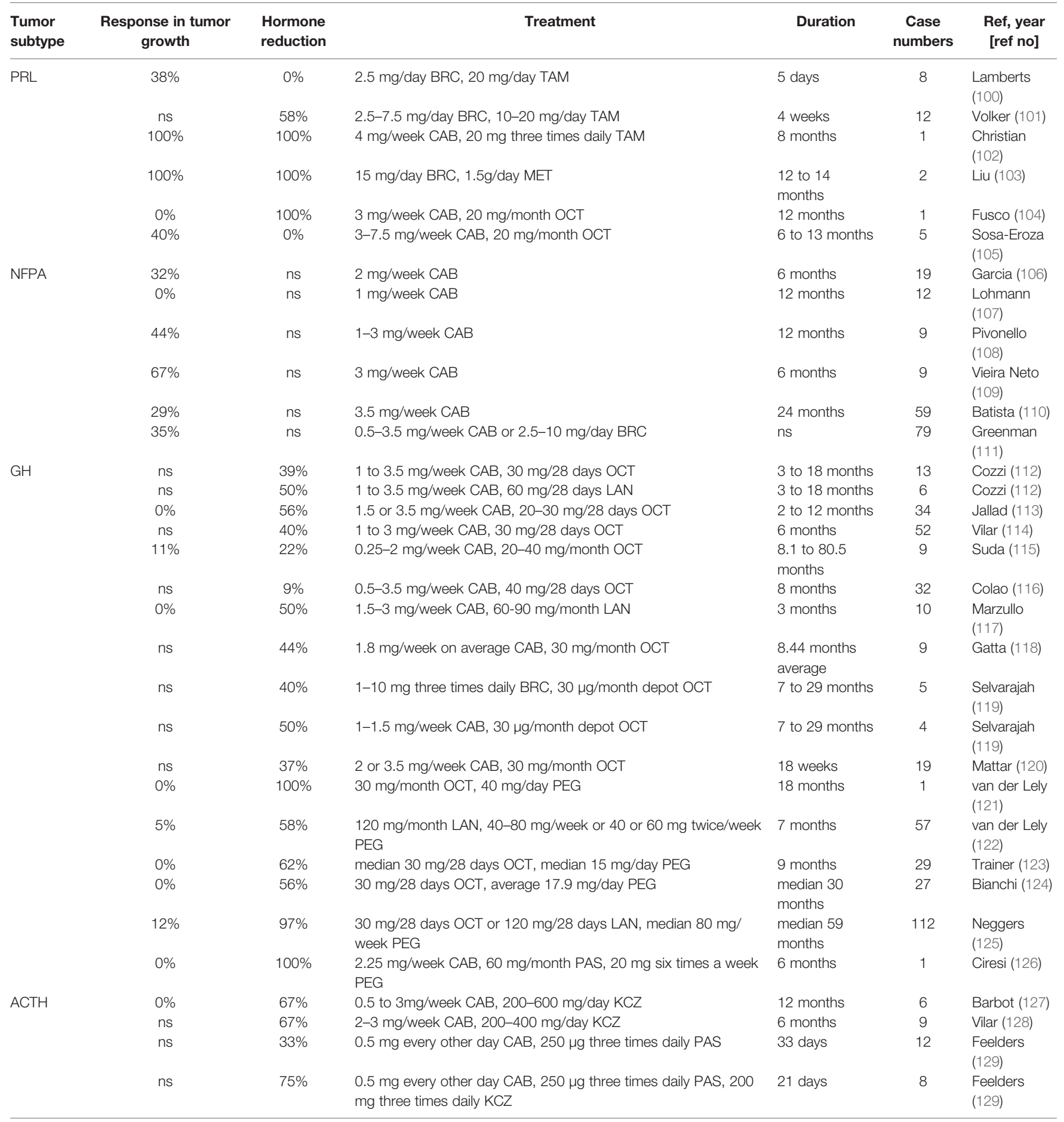

NFPA, non-functioning pituitary adenoma; ns, not stated; BRC, bromocriptine; TAM, tamoxifen; CAB, cabergoline; MET, metformin; OCT, octreotide; LAN, lanreotide; PEG, pegvisomant; KCZ, ketoconazole; PAS, pasireotide.

reduced expression of SSTRs (130). It is found that three combination therapies (DA, pegvisomant or both) with SSA are mildly to moderately effective against these SSA-resistant GH-secreting tumors. As summarized in Table 6, these conventional combination therapies have shown a wide range of efficacies for controlling hormone levels (9\%-100\%) (112126). The combination of PEG and SSA seems more effective than CAB and SSA to control IGF1 levels (112-126). None of the combinations are effective in reducing tumor size $(0 \%-12 \%)$ (112-120). 


\section{Combination Therapies for Aggressive Cushing Disease}

Only a limited number of studies report treatment of aggressive Cushing disease with combinations of conventional therapies [Table 6 (127-129)]. Ketoconazole (KCZ) in combination with $\mathrm{CAB}$ or PAS showed a moderate normalizing effect on cortisol levels in KCZ monotherapy resistant cases (129). CAB and PAS combinations were reported, but were less effective for reducing cortisol levels (129). One study showed no tumor reduction and the others did not mention efficacies on tumor size reductions.

\section{EPIDERMAL GROWTH FACTOR RECEPTOR (EGFR) INHIBITORS}

EGFR is a transmembrane receptor with the intracellular tyrosine kinase domain that regulates cell proliferation, migration, and survival. The EGFR inhibitors gefitinib and lapatinib are promising treatments for aggressive prolactinomas and aggressive corticotroph adenomas. EGFR signaling is detected in up to $82 \%$ of DA resistant prolactinomas. Activating EGFR signaling in rat lactosomatotroph cells causes elevation of $P R L$ mRNA expression (131). EGFR signaling also upregulates the POMC (proopiomelanocortin) promoter and increases ACTH production in corticotrophs (132). Mutations in the ubiquitin specific peptidase 8 (USP8) gene, which causes gain-of-function of USP8 protein, are highly prevalent in Cushing disease (133). It is thought that the mutations in USP8 cause enhanced EGFR signaling and are closely associated with development of Cushing disease (133-136).

Gefitinib has been implemented for treatment of both aggressive prolactinomas and corticotroph adenomas (137). Gefitinib suppressed PRL secretion by approximately $50 \%$ in human prolactinoma primary cultures in vitro. Moreover, gefitinib suppressed serum PRL levels by $40 \%-50 \%$ and tumor volume by $30 \%$ in somatotroph adenoma xenografted rodent models $(131,138)$. In primary cultures of ACTH-secreting human, canine, and murine adenomas, POMC mRNA was significantly suppressed by $63 \%-95 \%$ following treatment with gefitinib. In corticotroph adenoma xenografted mice, a 10-day course of treatment with gefitinib resulted in $40 \%$ inhibition of tumor growth (132).

Lapatinib is a dual EGFR inhibitor that inhibits both EGFR and human epidermal growth factor receptor 2 (HER2) (139). It has mostly been used to treat aggressive prolactinomas. A comparative study between lapatinib and gefitinib has found that lapatinib suppressed PRL levels more strongly in human prolactinoma primary cultures (60\% with lapatinib and $40 \%$ with gefitinib) (138). It has also been reported that lapatinib suppresses PRL secretion (by 72\%) and cell proliferation (by 80\%) in EGFR and HER2-expressing transgenic mice, which are models of prolactinomas (140). In addition, a recent clinical trial treating two patients with DA-resistant prolactinomas with lapatinib at a dosage of $1,250 \mathrm{mg} /$ day has reported $78 \%$ and $42 \%$ PRL suppression respectively with a $22 \%$ tumor reduction in the former and a stabilized tumor in the latter (28). These studies suggest that targeting EGFR signaling is a promising therapeutic strategy to, at least, populations of pituitary tumors with elevated EGFR signaling.

\section{CYCLIN DEPENDENT KINASE 2 (CDK2) INHIBITOR}

CDK2 interacts with Cyclin E to facilitate entry into the S phase of the cell cycle and protects cells against apoptosis (141). The CDK2 inhibitor, roscovitine, has been tested in phase I and II clinical trials against various malignancies, including non-small cell lung cancer and nasopharyngeal and hepatocellular carcinomas (142). Roscovitine is currently being evaluated in preclinical studies for its ability to treat Cushing disease. Roscovitine targets the CDK2/Cyclin E complexes that are highly expressed specifically in corticotroph tumors (143). Roscovitine has dual effects; inhibition of corticotroph tumor growth and suppression of transcription of $P O M C$, which encodes a precursor of ACTH $(32,143)$. It has been demonstrated that roscovitine can reduce pomc expression by over $50 \%$ in pituitary tumor transforming gene (PTTG) zebrafish model and reduced ACTH and corticosterone levels by $50 \%$ in corticotroph xenografted mice (143). In primary cells derived from human corticotroph tumors, roscovitine suppressed ACTH levels in five out of six tumors (83\%) (32). These reports suggest promising results and may become a new avenue of treatment of Cushing disease.

\section{RETINOIC ACID (RA)}

RA is a vitamin A derivative that interacts with RA receptors and retinoid $\mathrm{X}$ receptors and regulates transcription of downstream genes $(144,145)$. In terms of the effects on pituitary hormone genes, studies have found that the all-trans and 9-cis isomers of RA reduce the DNA-binding affinity of NURR1, a nuclear orphan receptor important for the transcription of $P O M C$ (146). 9-cis RA has also been found to activate the transcription of D2Rs, suggesting that RA may be effective against both corticotroph adenomas and prolactinomas (147). As of the publication of this review, studies of the application of RA in the treatment of pituitary tumors have focused on the treatment of corticotroph adenomas.

The majority of studies utilizing RA are pre-clinical. It has been shown that RA treatment inhibits ACTH production and tumor growth in murine and canine models of Cushing disease $(148,149)$. Two other clinical studies have been published using RA to treat aggressive Cushing disease $(33,34)$. In one prospective study, urinary free cortisol levels normalized in 4 of 16 patients after treatment with RA (33). In a recent clinical trial, over $50 \%$ cortisol suppression was observed in five of seven recurrent pituitary tumors, with normalization in three patients (34). Of note, one patient who was resistant to CAB therapy had normalized urinary free cortisol levels following the addition of RA in the treatment (33). Moreover, a study utilizing primary 
culture derived from 11 corticotroph adenomas found that the combination of $\mathrm{RA}+\mathrm{BRC}$ inhibited POMC transcription and ACTH production at higher levels than either alone in five of 11 cultures, indicating that RA+DA combination therapy may be a possible treatment for Cushing disease $(33,150)$. At this point, the use of RA remains at pre-clinical level, and further evidence is required to determine its efficacy.

\section{CONCLUSION}

Aggressive pituitary tumors can be resistant to conventional therapies, including surgery, radiotherapy, and medical treatment. TMZ is recommended as the first-line chemotherapy for treatment of aggressive pituitary tumors. However, TMZ has a high rate of relapse in the long term. Several lines of evidence suggest the use of novel therapy, such as CAPTEM, PRRT, EVE, immunotherapy, EGFR inhibitors, CDK2 inhibitors, and RA, could be valuable strategies for long-term tumor control. These novel therapies could improve inhibition of pituitary tumor growth and/or control of excess hormone(s) compared to established treatment methods. Although information about the efficacy of such

\section{REFERENCES}

1. Raverot G, Burman P, McCormack A, Heaney A, Petersenn S, Popovic V, et al. European Society of Endocrinology Clinical Practice Guidelines for the management of aggressive pituitary tumours and carcinomas. Eur J Endocrinol (2018) 178(1):G1-g24. doi: 10.1530/EJE-17-0796

2. Lasolle H, Cortet C, Castinetti F, Cloix L, Caron P, Delemer B, et al. Temozolomide treatment can improve overall survival in aggressive pituitary tumors and pituitary carcinomas. Eur J Endocrinol (2017) 176 (6):769-77. doi: 10.1530/EJE-16-0979

3. Bush ZM, Longtine JA, Cunningham T, Schiff D, Jane JA Jr, Vance ML, et al. Temozolomide treatment for aggressive pituitary tumors: correlation of clinical outcome with $\mathrm{O}(6)$-methylguanine methyltransferase (MGMT) promoter methylation and expression. J Clin Endocrinol Metab (2010) 95 (11):E280-90. doi: 10.1210/jc.2010-0441

4. Raverot G, Sturm N, de Fraipont F, Muller M, Salenave S, Caron P, et al. Temozolomide treatment in aggressive pituitary tumors and pituitary carcinomas: a French multicenter experience. J Clin Endocrinol Metab (2010) 95(10):4592-9. doi: 10.1210/jc.2010-0644

5. Losa M, Mazza E, Terreni MR, McCormack A, Gill AJ, Motta M, et al. Salvage therapy with temozolomide in patients with aggressive or metastatic pituitary adenomas: experience in six cases. Eur J Endocrinol (2010) 163 (6):843-51. doi: 10.1530/EJE-10-0629

6. Hirohata T, Asano K, Ogawa Y, Takano S, Amano K, Isozaki O, et al. DNA mismatch repair protein (MSH6) correlated with the responses ofatypical pituitary adenomas and pituitary carcinomas to temozolomide: the national cooperative studyby the Japan Society for Hypothalamic and Pituitary Tumors. J Clin Endocrinol Metab (2013) 98(3):1130-6. doi: 10.1210/ jc.2012-2924

7. Bruno OD, Juárez-Allen L, Christiansen SB, Manavela M, Danilowicz K, Vigovich C, et al. Temozolomide Therapy for Aggressive Pituitary Tumors: Results in a Small Series of Patients from Argentina. Int J Endocrinol (2015) 2015:587893. doi: 10.1155/2015/587893

8. Bengtsson D, Schrøder HD, Andersen M, Maiter D, Berinder K, Feldt Rasmussen U, et al. Long-term outcome and MGMT as a predictive marker in 24 patients with atypical pituitary adenomas and pituitary carcinomas treatments is limited and few cases have utilized them so far, some treatments are showing promising outcomes. Further research will establish new treatment options and optimize treatment sequencing for aggressive pituitary tumors.

\section{AUTHOR CONTRIBUTIONS}

TA and TT designed the project. TN-T, KL, and JW did literature searches and analyzed data. TA, TT, TN-T, KL, JW, CM, and YK wrote the manuscript. All authors contributed to the article and approved the submitted version.

\section{FUNDING}

This study is supported by grants from the Graduate School, University of Minnesota (UMF0011528 to TA, Grant-in-Aid 212588 to TA), the University of Alberta (Start-up to TT), the University Hospital Foundation (Medical Research Competition 2019 to TT), and the US National Institutes of Health (AR064195 to $\mathrm{YK})$. given treatment with temozolomide. J Clin Endocrinol Metab (2015) 100 (4):1689-98. doi: 10.1210/jc.2014-4350

9. Ceccato F, Lombardi G, Manara R, Emanuelli E, Denaro L, Milanese L, et al. Temozolomide and pasireotide treatment for aggressive pituitary adenoma: expertise at a tertiary care center. J Neurooncol (2015) 122(1):189-96. doi: 10.1007/s11060-014-1702-0

10. Losa M, Bogazzi F, Cannavo S, Ceccato F, Curtò L, De Marinis L, et al. Temozolomide therapy in patients with aggressive pituitary adenomas or carcinomas. J Neurooncol (2016) 126(3):519-25. doi: 10.1007/s11060-0151991-y

11. McCormack A, Dekkers OM, Petersenn S, Popovic V, Trouillas J, Raverot G, et al. Treatment of aggressive pituitary tumours and carcinomas: results ofa European Society of Endocrinology (ESE) survey 2016. Eur J Endocrinol (2018) 178(3):265-76. doi: 10.1530/eje-17-0933

12. Santos-Pinheiro F, Prado M, Kamiya-Matsuoka C, Waguespack SG, Mahajan A, Brown PD, et al. Treatment and long-term outcomes in pituitary carcinoma: a cohort study. Eur J Endocrinol (2019) 181(4):397407. doi: 10.1530/EJE-18-0795

13. Elbelt U, Schlaffer SM, Buchfelder M, Knappe UJ, Vila G, Micko A, et al. Efficacy of Temozolomide Therapy in Patients With Aggressive Pituitary Adenomas and Carcinomas-A German Survey. J Clin Endocrinol Metab (2020) 105(3). doi: 10.1210/clinem/dgz211

14. Zacharia BE, Gulati AP, Bruce JN, Carminucci AS, Wardlaw SL, Siegelin M, et al. High response rates and prolonged survival in patients with corticotroph pituitary tumors and refractory Cushing disease from capecitabine and temozolomide (CAPTEM): a case series. Neurosurgery (2014) 74(4):E447-55; discussion E455. doi: 10.1227/NEU.000000 0000000251

15. Nakano-Tateno T, Satou M, Inoshita N, van Landeghem FKH, Easaw J, Mehta V, et al. Effects of CAPTEM (Capecitabine and Temozolomide) on a Corticotroph Carcinoma and an Aggressive Corticotroph Tumor. Endocr Pathol (2020). doi: 10.1007/s12022-020-09647-w

16. Kumar Gupta S, Singla S, Damle NA, Agarwal K, Bal C. Diagnosis of Men-I Syndrome on (68)Ga-DOTANOC PET-CT and Role of Peptide Receptor Radionuclide Therapy With (177)Lu-DOTATATE. Int J Endocrinol Metab (2012) 10(4):629-33. doi: 10.5812/ijem.4313 
17. Baldari S, Ferraù F, Alafaci C, Herberg A, Granata F, Militano V, et al. First demonstration of the effectiveness of peptide receptor radionuclide therapy (PRRT) with 111In-DTPA-octreotide in a giant PRL-secreting pituitary adenoma resistant to conventional treatment. Pituitary (2012) 15 Suppl 1: S57-60. doi: 10.1007/s11102-011-0373-5

18. Komor J, Reubi JC, Christ ER. Peptide receptor radionuclide therapy in a patient with disabling non-functioning pituitary adenoma. Pituitary (2014) 17(3):227-31. doi: 10.1007/s11102-013-0494-0

19. Waligórska-Stachura J, Gut P, Sawicka-Gutaj N, Liebert W, Gryczyńska M, Baszko-Blaszyk D, et al. Growth hormone-secreting macroadenoma of the pituitary gland successfully treated with the radiolabeled somatostatin analog (90)Y-DOTATATE: case report. J Neurosurg (2016) 125(2):346-9. doi: 10.3171/2015.6.JNS15363

20. Maclean J, Aldridge M, Bomanji J, Short S, Fersht N. Peptide receptor radionuclide therapy for aggressive atypical pituitary adenoma/carcinoma: variable clinical response in preliminary evaluation. Pituitary (2014) 17 (6):530-8. doi: 10.1007/s11102-013-0540-y

21. Assadi M, Nemati R, Shooli H, Rekabpour SJ, Nabipour I, Jafari E, et al. An aggressive functioning pituitary adenoma treated with peptide receptor radionuclide therapy. Eur J Nucl Med Mol Imaging (2020) 47(4):1015-6. doi: 10.1007/s00259-019-04578-z

22. Novruzov F, Aliyev JA, Jaunmuktane F, Bomanji JB, Kayani I. The use of (68)Ga DOTATATE PET/CT for diagnostic assessment and monitoring of (177)Lu DOTATATE therapy in pituitary carcinoma. Clin Nucl Med (2015) 40(1):47-9. doi: 10.1097/RLU.0000000000000589

23. Giuffrida G, Ferraù F, Laudicella R, Cotta O, Messina E, Granata F, et al. Peptide receptor radionuclide therapy for aggressive pituitary tumors: a monocentric experience. Endocr Connect (2019) 8(5):528-35. doi: 10.1530/ EC-19-0065

24. Kovács GL, Góth M, Rotondo F, Scheithauer BW, Carlsen E, Saadia A, et al. ACTH-secreting Crooke cell carcinoma of the pituitary. Eur J Clin Invest (2013) 43(1):20-6. doi: 10.1111/eci.12010

25. Zhang D, Way JS, Zhang X, Sergey M, Bergsneider M, Wang MB, et al. Effect of Everolimus in Treatment of Aggressive Prolactin-Secreting Pituitary Adenomas. J Clin Endocrinol Metab (2019) 104(6):1929-36. doi: 10.1210/ jc.2018-02461

26. Alshaikh OM, Asa SL, Mete O, Ezzat S. An Institutional Experience of Tumor Progression to Pituitary Carcinoma in a 15-Year Cohort of 1055 Consecutive Pituitary Neuroendocrine Tumors. Endocr Pathol (2019) 30 (2):118-27. doi: 10.1007/s12022-019-9568-5

27. Jouanneau E, Wierinckx A, Ducray F, Favrel V, Borson-Chazot F, Honnorat J, et al. New targeted therapies in pituitary carcinoma resistant to temozolomide. Pituitary (2012) 15(1):37-43. doi: 10.1007/s11102-011-0341-0

28. Cooper O, Mamelak A, Bannykh S, Carmichael J, Bonert V, Lim S, et al. Prolactinoma ErbB receptor expression and targeted therapy for aggressive tumors. Endocrine (2014) 46(2):318-27. doi: 10.1007/s12020-013-0093-x

29. Lin AL, Jonsson P, Tabar V, Yang TJ, Cuaron J, Beal K, Lin AL, et al. Marked Response of a Hypermutated ACTH-Secreting Pituitary Carcinoma to Ipilimumab and Nivolumab. J Clin Endocrinol Metab (2018) 103 (10):3925-30. doi: 10.1210/jc.2018-01347

30. Sol B, de Filette JMK, Awada G, Raeymaeckers S, Aspeslagh S, Andreescu $\mathrm{CE}$, et al. Immune checkpoint inhibitor therapy for ACTH-secreting pituitary carcinoma: a new emerging treatment? Eur J Endocrinol (2021) 184(1):K1-5. doi: 10.1530/EJE-20-0151

31. Caccese M, Barbot M, Ceccato F, Padovan M, Gardiman MP, Fassan M, et al. Rapid disease progression in patient with mismatch-repair deficiency pituitary ACTH-secreting adenoma treated with checkpoint inhibitor pembrolizumab. Anticancer Drugs (2020) 31(2):199-204. doi: 10.1097/ CAD.0000000000000856

32. Liu NA, Araki T, Cuevas-Ramos D, Hong J, Ben-Shlomo A, Tone Y, et al. Cyclin E-Mediated Human Proopiomelanocortin Regulation as a Therapeutic Target for Cushing Disease. J Clin Endocrinol Metab (2015) 100(7):2557-64. doi: 10.1210/jc.2015-1606

33. Vilar L, Albuquerque JL, Lyra R, Trovão L, Diniz E, Rangel Filho F, et al. The Role of Isotretinoin Therapy for Cushing's Disease: Results of a Prospective Study. Int J Endocrinol (2016) 2016:8173182. doi: 10.1155/2016/8173182

34. Pecori Giraldi F, Ambrogio AG, Andrioli M, Sanguin F, Karamouzis I, Corsello SM, et al. Potential role for retinoic acid in patients with Cushing's disease. J Clin Endocrinol Metab (2012) 97(10):3577-83. doi: 10.1210/ jc. $2012-2328$

35. Stupp R, Mason WP, van den Bent MJ, Weller M, Fisher B, Taphoorn MJ, et al. Radiotherapy plus concomitant and adjuvant temozolomide for glioblastoma. N Engl J Med (2005) 352(10):987-96. doi: 10.1056/ NEJMoa043330

36. Lim S, Shahinian H, Maya MM, Yong W. Temozolomide: a novel treatment for pituitary carcinoma. Lancet Oncol (2006) 7(6):518-20. doi: 10.1016/ S1470-2045(06)70728-8

37. Syro LV, Uribe H, Penagos LC, Ortiz LD, Fadul CE, Horvath E, et al. Antitumour effects of temozolomide in a man with a large, invasive prolactin-producing pituitary neoplasm. Clin Endocrinol (Oxf) (2006) 65 (4):552-3. doi: 10.1111/j.1365-2265.2006.02653.x

38. Fadul CE, Kominsky AL, Meyer LP, Kingman LS, Kinlaw WB, Rhodes CH, et al. Long-term response of pituitary carcinoma to temozolomide. Report of two cases. J Neurosurg (2006) 105(4):621-6. doi: 10.3171/jns.2006.105.4.621

39. Liu L, Gerson SL. Targeted modulation of MGMT: clinical implications. Clin Cancer Res (2006) 12(2):328-31. doi: 10.1158/1078-0432.CCR-05-2543

40. Halevy C, Whitelaw BC. How effective is temozolomide for treating pituitary tumours and when should it be used? Pituitary (2017) 20(2):261-6. doi: 10.1007/s11102-016-0745-y

41. Ji Y, Vogel RI, Lou E. Temozolomide treatment of pituitary carcinomas and atypical adenomas: systematic review of case reports. Neurooncol Pract (2016) 3(3):188-95. doi: 10.1093/nop/npv059

42. Campderá M, Palacios N, Aller J, Magallón R, Martín P, Saucedo G, et al. Temozolomide for aggressive ACTH pituitary tumors: failure of a second course of treatment. Pituitary (2016) 19(2):158-66. doi: 10.1007/s11102-015-0694-x

43. Bilbao I, Egaña N, García C, Olaizola I, et al. Failure of a second temozolomide cycle in a patient with a prolactin-secreting pituitary carcinoma. Endocrinol Diabetes Nutr (2017) 64(10):564-6. doi: 10.1016/ j.endien.2017.08.007

44. Syro LV, Rotondo F, Camargo M, Ortiz LD, Serna CA, Kovacs K, et al. Temozolomide and Pituitary Tumors: Current Understanding, Unresolved Issues, and Future Directions. Front Endocrinol (Lausanne) (2018) 9:318. doi: $10.3389 /$ fendo. 2018.00318

45. McCormack AI, Wass JA, Grossman AB. Aggressive pituitary tumours: the role of temozolomide and theassessment of MGMT status. Eur J Clin Invest (2011)41:1133-48. doi: 10.1111/j.1365-2362.2011.02520.x

46. Mohammed AI, Cusimano MD, Scheithauer BW, Rotondo F, Horvath E, Kovacs K. O-methylguanine-DNA methyltransferase immunoexpression in a double pituitary adenoma: case report. Neurosurgery (2010) 66:E421-2; discussion E422. doi: 10.1227/01.Neu.0000363852.77126.Ad

47. Kovacs K, Scheithauer BW, Lombardero M, McLendon RE, Syro LV, Uribe H, et al. MGMT immunoexpression predicts responsiveness of pituitary tumors to temozolomide therapy. Acta Neuropathol (2008) 115:261-2. doi: 10.1007/ s00401-007-0279-5

48. McCormack AI, McDonald KL, Gill AJ, Clark SJ, Burt MG, Campbell KA, et al. Low O6-methylguanine-DNA methyltransferase (MGMT) expression and response to temozolomide in aggressive pituitary tumours. Clin Endocrinol (Oxf) (2009) 71:226-33. doi: 10.1111/j.1365-2265.2008.03487.x

49. Hagen C, Schroeder HD, Hansen S, Hagen C, Andersen M. Temozolomide treatment of a pituitary carcinoma and two pituitary macroadenomas resistant to conventional therapy. Eur J Endocrinol (2009) 161:631-7. doi: 10.1530/eje-09-0389

50. Whitelaw BC, Dworakowska D, Thomas NW, Barazi S, Riordan-Eva P, King AP, et al. Temozolomide in the management of dopamine agonist-resistant prolactinomas. Clin Endocrinol (Oxf) (2012) 76:877-86. doi: 10.1111/j.13652265.2012.04373.x

51. Annamalai AK, Dean AF, Kandasamy N, Kovacs K, Burton H, Halsall DJ, et al. Temozolomide responsiveness in aggressive corticotroph tumours: a case report and review of the literature. Pituitary (2012) 15:276-87. doi: 10.1007/s11102-011-0363-7

52. Yip S, Miao J, Cahill DP, Iafrate AJ, Aldape K, Nutt CL, et al. MSH6 mutations arise in glioblastomas during temozolomide therapy and mediate temozolomide resistance. Clin Cancer Res (2009) 15(14):4622-9. doi: 10.1158/1078-0432.CCR-08-3012

53. Murakami J, Lee YJ, Kokeguchi S, Tsujigiwa H, Asaumi J, Nagatsuka H, et al. Depletion of O6-methylguanine-DNA methyltransferase by O6- 
benzylguanine enhances 5-FU cytotoxicity in colon and oral cancer cell lines. Oncol Rep (2007) 17(6):1461-7. doi: 10.3892/or.17.6.1461

54. Kulke MH, Hornick JL, Frauenhoffer C, Hooshmand S, Ryan DP, Enzinger PC, et al. O6-methylguanine DNA methyltransferase deficiency and response to temozolomide-based therapy in patients with neuroendocrine tumors. Clin Cancer Res (2009) 15(1):338-45. doi: 10.1158/1078-0432.CCR08-1476

55. Fine RL, Gulati AP, Krantz BA, Moss RA, Schreibman S, Tsushima DA, et al. Capecitabine and temozolomide (CAPTEM) for metastatic, welldifferentiated neuroendocrine cancers: The Pancreas Center at Columbia University experience. Cancer Chemother Pharmacol (2013) 71(3):663-70. doi: $10.1007 / \mathrm{s} 00280-012-2055-\mathrm{z}$

56. Spiro TP, Liu L, Majka S, Haaga J, Willson JK, Gerson SL. Temozolomide: the effect of once- and twice-a-day dosing on tumor tissue levels of the DNA repair protein $\mathrm{O}(6)$-alkylguanine-DNA-alkyltransferase. Clin Cancer Res (2001) 7(8):2309-17.

57. Thearle MS, Freda PU, Bruce JN, Isaacson SR, Lee Y, Fine RL. Temozolomide $\left(\right.$ Temodar $^{\circledR}$ ) and capecitabine $\left(\right.$ Xeloda $\left.^{\circledR}\right)$ treatment of an aggressive corticotroph pituitary tumor. Pituitary (2011) 14(4):418-24. doi: 10.1007/s11102-009-0211-1

58. Donovan LE, Arnal AV, Wang SH, Odia Y. Widely metastatic atypical pituitary adenoma with mTOR pathway STK11(F298L) mutation treated with everolimus therapy. CNS Oncol (2016) 5(4):203-9. doi: 10.2217/cns2016-0011

59. Joehlin-Price AS, Hardesty DA, Arnold CA, Kirschner LS, Prevedello DM, Lehman NL. Case report: ACTH-secreting pituitary carcinoma metastatic to the liver in a patient with a history of atypical pituitary adenoma and Cushing's disease. Diagn Pathol (2017) 12(1):34. doi: 10.1186/s13000-0170624-5

60. Rotman LE, Vaughan TB, Hackney JR, Riley KO. Long-Term Survival After Transformation of an Adrenocorticotropic Hormone-Secreting Pituitary Macroadenoma to a Silent Corticotroph Pituitary Carcinoma. World Neurosurg (2019) 122:417-23. doi: 10.1016/j.wneu.2018.11.011

61. Touma W, Hoostal S, Peterson RA, Wiernik A, SantaCruz KS, Lou E. Successful treatment of pituitary carcinoma with concurrent radiation, temozolomide, and bevacizumab after resection. J Clin Neurosci (2017) 41:75-7. doi: 10.1016/j.jocn.2017.02.052

62. Wang Y, He Q, Meng X, Zhou S, Zhu Y, Xu J. Apatinib (YN968D1) and temozolomide in recurrent invasive pituitary adenoma: case report and literature review. World Neurosurg (2019) 124:319-22. doi: 10.1016/ j.wneu.2018.12.174

63. Bode H, Seiz M, Lammert A, Brockmann MA, Back W, Hammes HP. SOM230 (pasireotide) and temozolomide achieve sustained control of tumour progression and ACTH secretion in pituitary carcinoma with widespread metastases. Exp Clin Endocrinol Diabetes (2010) 118(10): 760-3. doi: $10.1055 / \mathrm{s}-0030-1253419$

64. Goglia U, Ferone D, Sidoti M, Spaziante R, Dadati P, Ravetti JL, et al. Treatment of a pituitary metastasis from a neuroendocrine tumour: case report and literature review. Pituitary (2008) 11(1):93-102. doi: 10.1007/ s11102-007-0038-6

65. Imhof A, Brunner P, Marincek N, Briel M, Schindler C, Rasch H, et al. Response, survival, and long-term toxicity after therapy with the radiolabeled somatostatin analogue [90Y-DOTA]-TOC in metastasized neuroendocrine cancers. J Clin Oncol (2011) 29(17):2416-23. doi: 10.1200/ JCO.2010.33.7873

66. Kwekkeboom DJ, de Herder WW, Krenning EP. Somatostatin receptortargeted radionuclide therapy in patients with gastroenteropancreatic neuroendocrine tumors. Endocrinol Metab Clin North Am (2011) 40 (1):173-85, ix. doi: 10.1016/j.ecl.2010.12.003

67. Krenning EP, de Jong M, Kooij PPM, Breeman WAP, Bakker WH, de Herder WW, et al. Radiolabelled somatostatin analogue(s) for peptide receptor scintigraphy and radionuclide therapy. Ann Oncol (1999) 10:S2330. doi: 10.1093/annonc/10.suppl_2.S23

68. Lapa C, Werner RA, Schmid JS, Papp L, Zsótér N, Biko J, et al. Prognostic value of positron emission tomography-assessed tumor heterogeneity in patients with thyroid cancer undergoing treatment with radiopeptide therapy. Nucl Med Biol (2015) 42(4):349-54. doi: 10.1016/ j.nucmedbio.2014.12.006
69. Werner RA, Lapa C, Ilhan H, Higuchi T, Buck AK, Lehner S, et al. Survival prediction in patients undergoing radionuclide therapy based on intratumoral somatostatin-receptor heterogeneity. Oncotarget (2017) 8 (4):7039-49. doi: 10.18632/oncotarget.12402

70. Engelman JA, Luo J, Cantley LC. The evolution of phosphatidylinositol 3kinases as regulators of growth and metabolism. Nat Rev Genet (2006) 7 (8):606-19. doi: $10.1038 / \mathrm{nrg} 1879$

71. Monsalves E, Juraschka K, Tateno T, Agnihotri S, Asa SL, Ezzat S, et al. The PI3K/ AKT/mTOR pathway in the pathophysiology and treatment of pituitary adenomas. Endocr Relat Cancer (2014) 21(4):R331-44. doi: 10.1530/ERC-14-0188

72. Musat M, Korbonits M, Kola B, Borboli N, Hanson MR, Nanzer AM, et al. Enhanced protein kinase B/Akt signalling in pituitary tumours. Endocr Relat Cancer (2005) 12(2):423-33. doi: 10.1677/erc.1.00949

73. Sajjad EA, Zieliński G, Maksymowicz M, Hutnik Ł, Bednarczuk T, Włodarski P. mTOR is frequently active in GH-secreting pituitary adenomas without influencing their morphopathological features. Endocr Pathol (2013) 24(1):11-9. doi: 10.1007/s12022-012-9230-y

74. Gorshtein A, Rubinfeld H, Kendler E, Theodoropoulou M, Cerovac V, Stalla GK, et al. Mammalian target of rapamycin inhibitors rapamycin and RAD001 (everolimus) induce anti-proliferative effects in GH-secreting pituitary tumor cells in vitro. Endocr Relat Cancer (2009) 16(3):1017-27. doi: 10.1677/ERC-08-0269

75. Lee M, Wiedemann T, Gross C, Leinhäuser I, Roncaroli F, Braren R, et al. Targeting PI3K/mTOR Signaling Displays Potent Antitumor Efficacy against Nonfunctioning Pituitary Adenomas. Clin Cancer Res (2015) 21 (14):3204-15. doi: 10.1158/1078-0432.CCR-15-0288

76. Chanal M, Chevallier P, Raverot V, Fonteneau G, Lucia K, Monteserin Garcia JL, et al. Differential Effects of PI3K and Dual PI3K/mTOR Inhibition in Rat Prolactin-Secreting Pituitary Tumors. Mol Cancer Ther (2016) 15 (6):1261-70. doi: 10.1158/1535-7163.MCT-15-0891

77. Pivonello C, Patalano R, Solari D, Auriemma RS, Frio F, Vitulli F, et al. Effect of combined treatment with a pan-PI3K inhibitor or an isoform-specific $\mathrm{PI} 3 \mathrm{~K}$ inhibitor and everolimus on cell proliferation in GH-secreting pituitary tumour in an experimental setting. Endocrine (2018) 62(3):663-80. doi: 10.1007/s12020-018-1677-2

78. Jalali S, Monsalves E, Tateno T, Zadeh G. Role of mTOR Inhibitors in Growth Hormone-Producing Pituitary Adenomas Harboring Different FGFR4 Genotypes. Endocrinology (2016) 157(9):3577-87. doi: 10.1210/en.2016-1028

79. Zatelli MC, Minoia M, Filieri C, Tagliati F, Buratto M, Ambrosio MR, et al. Effect of everolimus on cell viability in nonfunctioning pituitary adenomas. J Clin Endocrinol Metab (2010) 95(2):968-76. doi: 10.1210/jc.2009-1641

80. Cerovac V, Monteserin-Garcia J, Rubinfeld H, Buchfelder M, Losa M, Florio $\mathrm{T}$, et al. The somatostatin analogue octreotide confers sensitivity to rapamycin treatment on pituitary tumor cells. Cancer Res (2010) 70(2):66674. doi: 10.1158/0008-5472.CAN-09-2951

81. Darvin P, Toor SM, Sasidharan Nair V, Elkord E. Immune checkpoint inhibitors: recent progress and potential biomarkers. Exp Mol Med (2018) 50 (12):1-11. doi: 10.1038/s12276-018-0191-1

82. Hui E. Immune checkpoint inhibitors. J Cell Biol (2019) 218(3):740-1. doi: $10.1083 /$ jcb. 201810035

83. Mei Y, Bi WL, Greenwald NF, Du Z, Agar NY, Kaiser UB, et al. Increased expression of programmed death ligand 1 (PD-L1) in human pituitary tumors. Oncotarget (2016) 7(47):76565-76. doi: 10.18632/oncotarget.12088

84. Uraki S, Ariyasu H, Doi A, Takeshima K, Morita S, Inaba H, et al. MSH6/2 and PD-L1 Expressions Are Associated with Tumor Growth and Invasiveness in Silent Pituitary Adenoma Subtypes. Int J Mol Sci (2020) 21 (8). doi: 10.3390/ijms 21082831

85. Wang Z, Guo X, Gao L, Deng K, Lian W, Bao X, et al. The Immune Profile of Pituitary Adenomas and a Novel Immune Classification for Predicting Immunotherapy Responsiveness. J Clin Endocrinol Metab (2020) 105(9): e3207-23. doi: 10.1210/clinem/dgaa449

86. Albarel F, Gaudy C, Castinetti F, Carré T, Morange I, Conte-Devolx B, et al. Long-term follow-up of ipilimumab-induced hypophysitis, a common adverse event of the anti-CTLA-4 antibody in melanoma. Eur J Endocrinol (2015) 172(2):195-204. doi: 10.1530/EJE-14-0845

87. Naidoo J, Page DB, Li BT, Connell LC, Schindler K, Lacouture ME, et al. Toxicities of the anti-PD-1 and anti-PD-L1 immune checkpoint antibodies. Ann Oncol (2015) 26(12):2375-91. doi: 10.1093/annonc/mdv383 
88. Postow MA, Chesney J, Pavlick AC, Robert C, Grossmann K, McDermott D, et al. Nivolumab and ipilimumab versus ipilimumab in untreated melanoma. N Engl J Med (2015) 372(21):2006-17. doi: 10.1056/NEJMoa1414428

89. Larkin J, Chiarion-Sileni V, Gonzalez R, Grob JJ, Cowey CL, Lao CD, et al. Combined Nivolumab and Ipilimumab or Monotherapy in Untreated Melanoma. N Engl J Med (2015) 373(1):23-34. doi: 10.1056/NEJMoa1504030

90. Ferrari SM, Fallahi P, Galetta F, Citi E, Benvenga S, Antonelli A. Thyroid disorders induced by checkpoint inhibitors. Rev Endocr Metab Disord (2018) 19(4):325-33. doi: 10.1007/s11154-018-9463-2

91. Barroso-Sousa R, Barry WT, Garrido-Castro AC, Hodi FS, Min L, Krop IE, et al. Incidence of Endocrine Dysfunction Following the Use of Different Immune Checkpoint Inhibitor Regimens: A Systematic Review and Metaanalysis. JAMA Oncol (2018) 4(2):173-82. doi: 10.1001/ jamaoncol.2017.3064

92. Hodi FS, O'Day SJ, McDermott DF, Weber RW, Sosman JA, Haanen JB, et al. Improved survival with ipilimumab in patients with metastatic melanoma. $N$ Engl J Med (2010) 363(8):711-23. doi: 10.1056/ NEJMoa1003466

93. Tian Y, Abu-Sbeih H, Wang Y. Immune Checkpoint Inhibitors-Induced Hepatitis. Adv Exp Med Biol (2018) 995:159-64. doi: 10.1007/978-3-03002505-2_8

94. Duhamel C, Ilie MD, Salle H, Nassouri AS, Gaillard S, Deluche E, et al. Immunotherapy in Corticotroph and Lactotroph Aggressive Tumors and Carcinomas: Two Case Reports and a Review of the Literature. J Pers Med (2020) 10(3). doi: 10.3390/jpm10030088

95. Colao A, Savastano S. Medical treatment of prolactinomas. Nat Rev Endocrinol (2011) 7(5):267-78. doi: 10.1038/nrendo.2011.37

96. Maiter D. Management of Dopamine Agonist-Resistant Prolactinoma. Neuroendocrinology (2019) 109(1):42-50. doi: 10.1159/000495775

97. Recouvreux MV, Camilletti MA, Rifkin DB, Díaz-Torga G. The pituitary TGF $\beta 1$ system as a novel target for the treatment of resistant prolactinomas. J Endocrinol (2016) 228(3):R73-83. doi: 10.1530/JOE-15-0451

98. Ono M, Miki N, Kawamata T, Makino R, Amano K, Seki T, et al. Prospective study of high-dose cabergoline treatment of prolactinomas in 150 patients. J Clin Endocrinol Metab (2008) 93(12):4721-7. doi: 10.1210/jc.2007-2758

99. Zanettini R, Antonini A, Gatto G, Gentile R, Tesei S, Pezzoli G. Valvular heart disease and the use of dopamine agonists for Parkinson's disease. N Engl J Med (2007) 356(1):39-46. doi: 10.1056/NEJMoa054830

100. Lamberts SW, Verleun T, Oosterom R. Effect of tamoxifen administration on prolactin release by invasive prolactin-secreting pituitary adenomas. Neuroendocrinology (1982) 34(5):339-42. doi: 10.1159/000123324

101. Völker W, Gehring WG, Berning R, Schmidt RC, Schneider J, von zur Mühlen A. Impaired pituitary response to bromocriptine suppression: reversal after bromocriptine plus tamoxifen. Acta Endocrinol (Copenh) (1982) 101(4):491-500. doi: 10.1530/acta.0.1010491

102. Christian ZK, Hatanpaa KJ, Auchus RJ, Hammes SR, Patel AR, Mickey BE. Dopamine agonist and tamoxifen combination therapy for a prolactinsecreting pituitary tumor resistant to dopamine agonist monotherapy: Case report and review. Interdiscip Neurosurg (2020) 21:100777. doi: 10.1016/j.inat.2020.100777

103. Liu X, Liu Y, Gao J, Feng M, Bao X, Deng K, et al. Combination Treatment with Bromocriptine and Metformin in Patients with BromocriptineResistant Prolactinomas: Pilot Study. World Neurosurg (2018) 115:94-8. doi: 10.1016/j.wneu.2018.02.188

104. Fusco A, Lugli F, Sacco E, Tilaro L, Bianchi A, Angelini F, et al. Efficacy of the combined cabergoline and octreotide treatment in a case of a dopamineagonist resistant macroprolactinoma. Pituitary (2011) 14(4):351-7. doi: 10.1007/s11102-008-0162-y

105. Sosa-Eroza E, Espinosa E, Ramírez-Rentería C, Mendoza V, Arreola R, Mercado M. Treatment of multiresistant prolactinomas with a combination of cabergoline and octreotide LAR. Endocrine (2018) 61(2):343-8. doi: 10.1007/s12020-018-1638-9

106. Garcia EC, Naves LA, Silva AO, de Castro LF, Casulari LA, Azevedo MF. Short-term treatment with cabergoline can lead to tumor shrinkage in patients with nonfunctioning pituitary adenomas. Pituitary (2013) 16 (2):189-94. doi: 10.1007/s11102-012-0403-y

107. Lohmann T, Trantakis C, Biesold M, Prothmann S, Guenzel S, Schober R, et al. Minor tumour shrinkage in nonfunctioning pituitary adenomas by long-term treatment with the dopamine agonist cabergoline. Pituitary (2001) 4(3):173-8. doi: 10.1023/a:1015366923810

108. Pivonello R, Matrone C, Filippella M, Cavallo LM, Di Somma C, Cappabianca $\mathrm{P}$, et al. Dopamine receptor expression and function in clinically nonfunctioning pituitary tumors: comparison with the effectiveness of cabergoline treatment. J Clin Endocrinol Metab (2004) 89 (4):1674-83. doi: 10.1210/jc.2003-030859

109. Vieira Neto L, Wildemberg LE, Moraes AB, Colli LM, Kasuki L, Marques $\mathrm{NV}$, et al. Dopamine receptor subtype 2 expression profile in nonfunctioning pituitary adenomas and in vivo response to cabergoline therapy. Clin Endocrinol (Oxf) (2015) 82(5):739-46. doi: 10.1111/cen.12684

110. Batista RL, Musolino NRC, Cescato VAS, da Silva GO, Medeiros RSS, Herkenhoff CGB, et al. Cabergoline in the Management of Residual Nonfunctioning Pituitary Adenoma: A Single-Center, Open-Label, 2-Year Randomized Clinical Trial. Am J Clin Oncol (2019) 42(2):221-7. doi: 10.1097/COC.0000000000000505

111. Greenman Y, Cooper O, Yaish I, Robenshtok E, Sagiv N, Jonas-Kimchi T, et al. Treatment of clinically nonfunctioning pituitary adenomas with dopamine agonists. Eur J Endocrinol (2016) 175(1):63-72. doi: 10.1530/ EJE-16-0206

112. Cozzi R, Attanasio R, Lodrini S, Lasio G. Cabergoline addition to depot somatostatin analogues in resistant acromegalic patients: efficacy and lack of predictive value of prolactin status. Clin Endocrinol (Oxf) (2004) 61(2):20915. doi: 10.1111/j.1365-2265.2004.02082.x

113. Jallad RS, Bronstein MD. Optimizing medical therapy of acromegaly: beneficial effects of cabergoline in patients uncontrolled with long-acting release octreotide. Neuroendocrinology (2009) 90(1):82-92. doi: 10.1159/ 000218323

114. Vilar L, Azevedo MF, Naves LA, Casulari LA, Albuquerque JL, Montenegro $\mathrm{RM}$, et al. Role of the addition of cabergoline to the management of acromegalic patients resistant to longterm treatment with octreotide LAR. Pituitary (2011) 14(2):148-56. doi: 10.1007/s11102-010-0272-1

115. Suda K, Inoshita N, Iguchi G, Fukuoka $\mathrm{H}$, Takahashi $\mathrm{M}$, Nishizawa $\mathrm{H}$, et al. Efficacy of combined octreotide and cabergoline treatment in patients with acromegaly: a retrospective clinical study and review of the literature. Endocr $J$ (2013) 60(4):507-15.

116. Colao A, Zgliczyński W, Komorowski J, Kos-Kudla B, Tabarin A, Kerlan V, et al. Efficacy and safety of high-dose long-acting repeatable octreotide as monotherapy or in combination with pegvisomant or cabergoline in patients with acromegaly not adequately controlled by conventional regimens: results of an open-label, multicentre study. Endokrynol Pol (2019) 70(4):305-12. doi: 10.5603/EP.a2019.0023

117. Marzullo P, Ferone D, Di Somma C, Pivonello R, Filippella M, Lombardi G, et al. Efficacy of combined treatment with lanreotide and cabergoline in selected therapy-resistant acromegalic patients. Pituitary (1999) 1(2):115-20. doi: 10.1023/a:1009932521242

118. Gatta B, Hau DH, Catargi B, Roger P, Tabarin A. Re-evaluation of the efficacy of the association of cabergoline to somatostatin analogues in acromegalic patients. Clin Endocrinol (Oxf) (2005) 63(4):477-8. doi: 10.1111/j.1365-2265.2005.02329.x

119. Selvarajah D, Webster J, Ross R, Newell-Price J. Effectiveness of adding dopamine agonist therapy to long-acting somatostatin analogues in the management of acromegaly. Eur J Endocrinol (2005) 152(4):569-74. doi: 10.1530/eje.1.01888

120. Mattar P, Alves Martins MR, Abucham J. Short- and long-term efficacy of combined cabergoline and octreotide treatment in controlling igf-I levels in acromegaly. Neuroendocrinology (2010) 92(2):120-7. doi: 10.1159/ 000317314

121. van der Lely AJ, Muller A, Janssen JA, Davis RJ, Zib KA, Scarlett JA, et al. Control of tumor size and disease activity during cotreatment with octreotide and the growth hormone receptor antagonist pegvisomant in an acromegalic patient. J Clin Endocrinol Metab (2001) 86(2):478-81. doi: 10.1210/ jcem.86.2.7206

122. van der Lely AJ, Bernabeu I, Cap J, Caron P, Colao A, Marek J, et al. Coadministration of lanreotide Autogel and pegvisomant normalizes IGF1 levels and is well tolerated in patients with acromegaly partially controlled by somatostatin analogs alone. Eur J Endocrinol (2011) 164(3):325-33. doi: 10.1530/EJE-10-0867 
123. Trainer PJ, Ezzat S, D'Souza GA, Layton G, Strasburger CJ. A randomized, controlled, multicentre trial comparing pegvisomant alone with combination therapy of pegvisomant and long-acting octreotide in patients with acromegaly. Clin Endocrinol (Oxf) (2009) 71(4):549-57. doi: 10.1111/ j.1365-2265.2009.03620.x

124. Bianchi A, Valentini F, Iuorio R, Poggi M, Baldelli R, Passeri M, et al. Longterm treatment of somatostatin analog-refractory growth hormone-secreting pituitary tumors with pegvisomant alone or combined with long-acting somatostatin analogs: a retrospective analysis of clinical practice and outcomes. J Exp Clin Cancer Res (2013) 32(1):40. doi: 10.1186/1756-9966$32-40$

125. Neggers SJ, Franck SE, de Rooij FW, Dallenga AH, Poublon RM, Feelders RA, et al. Long-term efficacy and safety of pegvisomant in combination with long-acting somatostatin analogs in acromegaly. J Clin Endocrinol Metab (2014) 99(10):3644-52. doi: 10.1210/jc.2014-2032

126. Ciresi A, Radellini S, Guarnotta V, Giordano C. Efficacy of combined treatment with pasireotide, pegvisomant and cabergoline in an acromegalic patient resistant to other treatments: a case report. $B M C$ Endocr Disord (2018) 18(1):2. doi: 10.1186/s12902-018-0231-9

127. Barbot M, Albiger N, Ceccato F, Zilio M, Frigo AC, Denaro L, et al. Combination therapy for Cushing's disease: effectiveness of two schedules of treatment: should we start with cabergoline or ketoconazole? Pituitary (2014) 17(2):109-17. doi: 10.1007/s11102-013-0475-3

128. Vilar L, Naves LA, Azevedo MF, Arruda MJ, Arahata CM, Moura ESL, et al. Effectiveness of cabergoline in monotherapy and combined with ketoconazole in the management of Cushing's disease. Pituitary (2010) 13 (2):123-9. doi: 10.1007/s11102-009-0209-8

129. Feelders RA, de Bruin C, Pereira AM, Romijn JA, Netea-Maier RT, Hermus $\mathrm{AR}$, et al. Pasireotide alone or with cabergoline and ketoconazole in Cushing's disease. N Engl J Med (2010) 362(19):1846-8. doi: 10.1056/ NEJMc1000094

130. Peverelli E, Treppiedi D, Giardino E, Vitali E, Lania AG, Mantovani G. Dopamine and Somatostatin Analogues Resistance of Pituitary Tumors: Focus on Cytoskeleton Involvement. Front Endocrinol (Lausanne) (2015) 6:187. doi: 10.3389/fendo.2015.00187

131. Vlotides G, Siegel E, Donangelo I, Gutman S, Ren SG, Melmed S, et al. Rat prolactinoma cell growth regulation by epidermal growth factor receptor ligands. Cancer Res (2008) 68(15). doi: 10.1158/0008-5472.CAN-08-0508

132. Fukuoka H, Cooper O, Ben-Shlomo A, Mamelak A, Ren SG, Bruyette D, et al. EGFR as a therapeutic target for human, canine, and mouse ACTHsecreting pituitary adenomas. J Clin Invest (2011) 121(12):4712-21. doi: 10.1172/JCI60417

133. Reincke M, Sbiera S, Hayakawa A, Theodoropoulou M, Osswald A, Beuschlein F, et al. Mutations in the deubiquitinase gene USP8 cause Cushing's disease. Nat Genet (2015) 47(1):31-8. doi: 10.1038/ng.3166

134. Ma ZY, Song ZJ, Chen JH, Wang YF, Li SQ, Zhou LF, et al. Recurrent gainof-function USP8 mutations in Cushing's disease. Cell Res (2015) 25(3):30617. doi: $10.1038 / \mathrm{cr} .2015 .20$

135. Weigand I, Knobloch L, Flitsch J, Saeger W, Monoranu CM, Höfner K, et al. Impact of USP8 Gene Mutations on Protein Deregulation in Cushing Disease. J Clin Endocrinol Metab (2019) 104(7):2535-46. doi: 10.1210/ jc.2018-02564

136. Wanichi IQ, de Paula Mariani BM, Frassetto FP, Siqueira SAC, de Castro Musolino NR, Cunha-Neto MBC, et al. Cushing's disease due to somatic USP8 mutations: a systematic review and meta-analysis. Pituitary (2019) 22 (4):435-42. doi: 10.1007/s11102-019-00973-9

137. Nurwidya F, Takahashi F, Takahashi K. Gefitinib in the treatment of nonsmall cell lung cancer with activating epidermal growth factor receptor mutation. J Nat Sci Biol Med (2016) 7(2):119-23. doi: 10.4103/09769668.184695
138. Fukuoka H, Cooper O, Mizutani J, Tong Y, Ren SG, Bannykh S, et al. HER2/ ErbB2 receptor signaling in rat and human prolactinoma cells: strategy for targeted prolactinoma therapy. Mol Endocrinol (2011) 25(1):92-103. doi: 10.1210/me.2010-0353

139. Opdam FL, Guchelaar HJ, Beijnen JH, Schellens JH. Lapatinib for advanced or metastatic breast cancer. Oncologist (2012) 17(4):536-42. doi: 10.1634/ theoncologist.2011-0461

140. Liu X, Kano M, Araki T, Cooper O, Fukuoka H, Tone Y, et al. ErbB receptordriven prolactinomas respond to targeted lapatinib treatment in female transgenic mice. Endocrinology (2015) 156(1):71-9. doi: 10.1210/en.20141627

141. Tadesse S, Caldon EC, Tilley W, Wang S. Cyclin-Dependent Kinase 2 Inhibitors in Cancer Therapy: An Update. J Med Chem (2019) 62(9):423351. doi: 10.1021/acs.jmedchem.8b01469

142. Cicenas J, Kalyan K, Sorokinas A, Stankunas E, Levy J, Meskinyte I, et al. Roscovitine in cancer and other diseases. Ann Transl Med (2015) 3(10):135. doi: 10.3978/j.issn.2305-5839.2015.03.61

143. Liu NA, Jiang H, Ben-Shlomo A, Wawrowsky K, Fan XM, Lin S, et al. Targeting zebrafish and murine pituitary corticotroph tumors with a cyclindependent kinase (CDK) inhibitor. Proc Natl Acad Sci USA (2011) 108 (20):8414-9. doi: 10.1073/pnas.1018091108

144. Massaro F, Molica M, Breccia M. Current first- and second-line treatment options in acute promyelocytic leukemia. Int J Hematol Oncol (2016) 5 (3):105-18. doi: 10.2217/ijh-2016-0010

145. Labeur M, Paez-Pereda M, Arzt E, Stalla GK. Potential of retinoic acid derivatives for the treatment of corticotroph pituitary adenomas. Rev Endocr Metab Disord (2009) 10(2):103-9. doi: 10.1007/s11154-008-9080-6

146. Kang HJ, Song MR, Lee SK, Shin EC, Choi YH, Kim SJ, et al. Retinoic acid and its receptors repress the expression and transactivation functions of Nur77: a possible mechanism for the inhibition of apoptosis by retinoic acid. Exp Cell Res (2000) 256(2):545-54. doi: 10.1006/excr.2000.4832

147. Bondioni S, Angioni AR, Corbetta S, Locatelli M, Ferrero S, Ferrante E, et al. Effect of 9-cis retinoic acid on dopamine D2 receptor expression in pituitary adenoma cells. Exp Biol Med (Maywood) (2008) 233(4):439-46. doi: 10.3181/ 0704-RM-94

148. Páez-Pereda M, Kovalovsky D, Hopfner U, Theodoropoulou M, Pagotto U, Uhl E, et al. Retinoic acid prevents experimental Cushing syndrome. J Clin Invest (2001) 108(8):1123-31. doi: 10.1172/JCI11098

149. Castillo V, Giacomini D, Páez-Pereda M, Stalla J, Labeur M, Theodoropoulou $\mathrm{M}$, et al. Retinoic acid as a novel medical therapy for Cushing's disease in dogs. Endocrinology (2006) 147(9):4438-44. doi: 10.1210/en.2006-0414

150. Occhi G, Regazzo D, Albiger NM, Ceccato F, Ferasin S, Scanarini M, et al. Activation of the dopamine receptor type-2 (DRD2) promoter by 9-cis retinoic acid in a cellular model of Cushing's disease mediates the inhibition of cell proliferation and ACTH secretion without a complete corticotrophto-melanotroph transdifferentiation. Endocrinology (2014) 155(9):3538-49. doi: $10.1210 /$ en.2013-1820

Conflict of Interest: The authors declare that the research was conducted in the absence of any commercial or financial relationships that could be construed as a potential conflict of interest.

Copyright (c) 2021 Nakano-Tateno, Lau, Wang, McMahon, Kawakami, Tateno and Araki. This is an open-access article distributed under the terms of the Creative Commons Attribution License (CC BY). The use, distribution or reproduction in other forums is permitted, provided the original author(s) and the copyright owner(s) are credited and that the original publication in this journal is cited, in accordance with accepted academic practice. No use, distribution or reproduction is permitted which does not comply with these terms. 